\title{
ECHMERIT V1.0 - a new global fully coupled mercury-chemistry and transport model
}

\author{
G. Jung, I. M. Hedgecock, and N. Pirrone \\ IIA-CNR, Institute of Atmospheric Pollution Research, Italian National Research Council, c/o UNICAL, 87036 Rende, Italy
}

Received: 29 April 2009 - Published in Geosci. Model Dev. Discuss.: 7 May 2009

Revised: 17 October 2009 - Accepted: 23 October 2009 - Published: 4 November 2009

\begin{abstract}
Mercury is a global pollutant due to its long lifetime in the atmosphere. Its hemispheric transport patterns and eventual deposition are therefore of major concern. For the purpose of global atmospheric mercury chemistry and transport modelling the ECHMERIT model was developed. ECHMERIT, based on the global circulation model ECHAM5 differs from most global mercury models in that the emissions, chemistry (including general tropospheric chemistry and mercury chemistry), transport and deposition are coupled on-line to the GCM. The chemistry mechanism includes an online calculation of photolysis rate constants using the Fast-J photolysis mechanism, the CBM-Z tropospheric gas-phase mechanism and aqueous-phase chemistry based on the MECCA mechanism. Additionally, a mercury chemistry mechanism that incorporates gas and aqueous phase mercury chemistry is included. A detailed description of the model, including the wet and dry deposition modules, and the implemented emissions is given in this technical report. First model testing and evaluation show a satisfactory model performance for surface ozone and mercury mixing ratios (with a mean bias of $1.46 \mathrm{nmol} / \mathrm{mol}$ for ozone and a mean bias of $13.55 \mathrm{fmol} / \mathrm{mol}$ for TGM when compared with EMEP station data). Requirements regarding measurement data and emission inventories which could considerably improve model skill are discussed.
\end{abstract}

\section{Introduction}

While local and regional emission sources are the main cause of air pollution problems worldwide, there is increasing ev-

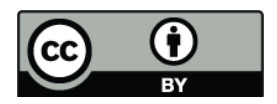

Correspondence to: G. Jung

(g.jung@cs.iia.cnr.it) idence that many air pollutants are transported on a hemispheric or global scale and are hence altering air quality even in remote areas (Stohl et al., 2002; Liang et al., 2004; Eckhardt et al., 2003; Lindberg et al., 2007). Mercury is a global pollutant because in its elemental form it reacts relatively slowly with the most abundant atmospheric oxidants and is therefore transported far from its emission sources. In fact the background concentration of $\mathrm{Hg}$ at the poles is similar to that in rural areas of Europe (Sprovieri et al., 2002). Additionally, mercury is of public concern, as it bioaccumulates, which can lead to very high levels of mercury compounds, especially in predators, at the end of the food chain (Lubick, 2009).

A recent summary of current knowledge on mercury emissions, chemistry and also modelling can be found in the interim report of the UNEP Global Partnership on Atmospheric Mercury Transport and Fate Research (Pirrone and Mason, 2008).

Mercury is released to the atmosphere from a variety of natural sources, such as volcanoes, surface waters, soil and vegetation, as well as from anthropogenic sources, particularly fossil fuel combustion, processing of mineral resources, chlor-alkali plants and waste incineration (Pirrone et al., 1996; Schroeder et al., 1998; Pacyna et al., 2006). Subsequently mercury is subject to chemical transformation, atmospheric transport, wet and dry deposition and potential bioaccumulation in the biosphere. Emissions from water bodies are estimated to be $2778 \mathrm{Mgy}^{-1}$ according to Pirrone and Mason (2009), which is $33 \%$ of the total $\mathrm{Hg}$ emissions to the atmosphere. Including all natural sources (volcanic activity, vegetation, soils, rocks, forest fires and oceans) results in annual global emissions of $5207 \mathrm{Mg}$ (Pirrone and Mason, 2008). Different estimates for anthropogenic mercury emissions exist and are continuously updated. Estimates range from $1484 \mathrm{Mgy}^{-1}$ (AMAP/UNEP, 2008) and $1894 \mathrm{Mgy}^{-1}$

Published by Copernicus Publications on behalf of the European Geosciences Union. 
in a recent estimate of Streets et al. (2009) (for 2005/2006 emissions) to $2503 \mathrm{Mgy}^{-1}$ in an estimate of Pirrone and Mason (2008) for emissions of the year 2000. The largest differences in the inventories can be attributed to a decrease in coal and oil combustion emissions due to technological developments and due to the implementation of updates of emissions from Australia and South Africa. Of the natural emissions, only one third is assumed to be not influenced by past anthropogenic activities at all. The other two-thirds of the "natural" emissions are considered to be re-emission of previously deposited $\mathrm{Hg}$ resulting from anthropogenic activity. Nevertheless, distinguishing between natural emissions of mercury and mercury which was previously deposited and is re-emitted from land surfaces, vegetation and water bodies is hardly possible (Pirrone et al., 1996).

Three types of mercury species are measured in the atmosphere. Elemental mercury, which is almost insoluble makes up the major part of the atmospheric Hg reservoir (95-99\%), whereas reactive gaseous mercury (RGM) is about $3 \%$ of the amount of elemental mercury (Bullock, 2000). RGM is an operationally defined term which refers to oxidised compounds which are collected on $\mathrm{KCl}$ denuders, and detected as elemental mercury $\left(\mathrm{Hg}^{0}\right)$ after thermal reduction and desorption. Oxidised $\mathrm{Hg}$ compounds are more chemically reactive and soluble than elemental mercury, and therefore easily scavenged in cloud droplets where they can take part in aqueous phase reactions. RGM is therefore also more strongly affected by wet and dry deposition processes than the less reactive and less soluble elemental mercury. Hence, even though it is the less abundant of the gas phase atmospheric $\mathrm{Hg}$ species, RGM is responsible for the major part of $\mathrm{Hg}$ removal from the atmosphere. RGM is assumed to include gaseous $\mathrm{Hg}^{\mathrm{II}}$ compounds such as $\mathrm{HgCl}_{2}, \mathrm{HgO}$ or $\mathrm{HgBr}_{2}$ (compare to the discussion in Sect. 2.3). Mercury associated with particulate matter $\left(\mathrm{Hg}_{\mathrm{p}}\right)$ is also found in the atmosphere, and is deposited but makes up only about $0.2-1.4 \%$ of total atmopheric $\mathrm{Hg}$ (Ebinghaus et al., 2008). $\mathrm{Hg}_{\mathrm{p}}$ is either primary particulate matter or condensed $\mathrm{Hg}$ compounds, or semi-volatile $\mathrm{Hg}$ bound to aerosols. The different chemical and physical characteristics of $\mathrm{Hg}$ species greatly influence their atmospheric lifetime. Because RGM is rapidly removed from the atmosphere it has a resulting lifetime in the order of days to weeks. Elemental $\mathrm{Hg}$ is in contrast, due to its long lifetime of 0.5-2 years (Hedgecock and Pirrone, 2004), transported over long distances. This means also that the relationship between emissions, atmospheric concentrations, and deposition is much less straightforward, than for shortlived chemical species, and hence interhemispheric transport plays a major role in mercury chemistry modelling.

Mercury concentrations and gradients are rather constant in both hemispheres, with background values of total gaseous mercury (TGM, the sum of RGM and $\mathrm{Hg}^{0}$ ) of around 1.1$1.3 \mathrm{ngm}^{-3}$ in the Southern and 1.5 to $1.7 \mathrm{ngm}^{-3}$ in the Northern Hemisphere (Lindberg et al., 2007).
The enhancement of mercury emissions starting with industrialization led to an increase in mercury concentrations by a factor of three, compared to pre-industrial times (Lindberg et al., 2007). In the lower troposphere and in surface levels $\mathrm{Hg}$ concentrations decreased from the late 1980's to 1990's (Slemr et al., 2003). Observations at Mace Head, a background station in Ireland, demonstrated almost constant concentrations from 1995 to 2001 (Ebinghaus et al., 2002), whereas observations on the Wank summit in Germany and over the Atlantic Ocean by Slemr and Scheel (1998) even showed a decrease over the entire 1990s. European emissions show a decrease of a factor of more than 4 from 1980 to 2005 , but for the years from 2003 to 2005 a strong increase in mercury concentrations, in air, but also in precipitation can be observed for Europe (Pacyna et al., 2009). This underlines the impact of long-range transport, as it might be attributed to the recent emission growth in the developing economies of South and East Asia. Otherwise also the impact of meterology and inter-annual variabilities of transport pattern might be considered as possible reason for this increase in mercury concentrations.

To investigate not only chemical transformation processes, but also the influence of long-range transport on the global and continental distribution of mercury concentrations, hemispheric and global mercury-chemistry models had to be developed. Not many atmospheric mercury chemistry and transport models exist so far.

On the hemispheric scale, the Danish Eulerian Hemispheric Model (DEHM) (Christensen et al., 2004) was used to investigate the mercury cycle and concentrations in the Northern Hemisphere, with a special focus on Arctic mercury depletion events. DEHM is an offline, Eulerian model where mercury chemistry includes gas and aqueous phase chemistry, as well as fast oxidation at polar sunrise.

Another offline large-scale model, working on the hemispheric scale, is the MSCE-Hg-Hem (Travnikov, 2005), of the Meteorological Synthesizing Centre East, Moscow. It runs at a relatively coarse resolution with 8 vertical layers and a horizontal resolution of $2.5^{\circ}$. It includes gas and aqueous phase oxidation by $\mathrm{O}_{3}$, chlorine, $\mathrm{OH}$ and aqueous-phase reduction via decomposition of sulphite complexes, the formation of chloride complexes and adsorption by soot particles in cloud water, where monthly mean concentrations for the reactants are used. For the boundary condition a fixed gradient of elemental mercury concentration is set at the equator. MSCE-Hg-Hem has been widely tested. Investigating hemispheric transport it was demonstrated, that even in industrialized regions, the contribution from intercontinental atmospheric transport is comparable with that of regional emissions.

On the global scale, the mercury chemistry version of the GEOS-chem model (Bey et al., 2001), an offline CTM including mercury chemistry, driven with assimilated meteorological data from the Goddard Earth Observing System (GEOS) of the NASA Data Assimilation Office (DAO) 
demonstrated reasonable results in reproducing mercury concentrations and concentration gradients in both hemispheres. GEOS-chem for $\mathrm{Hg}$ has so far been run in a resolution of $4 \times 5^{\circ}$ and 30 vertical levels and is coupled to a mixed-layer slab ocean model. It includes oxidation by $\mathrm{OH}$ and $\mathrm{O}_{3}$ in the gas phase and photochemical reduction in clouds.

CTM-Hg (Global Chemical Transport Model for Mercury) developed by AER/EPRI (Atmospheric and Environmental Research, Inc./Electric Power Research Institute) (Seigneur et al., 2001, 2004) is another global scale offline model that runs with a resolution of $8 \times 10^{\circ}$ and nine vertical layers but has a rather complex chemistry included, that considers gasand aqueous-phase oxidation and aqueous-phase reduction of $\mathrm{Hg}$ species. The sensitivity of CTM-Hg to the chemical mechanism and specific reaction rate constants (Seigneur et al., 2006, 2003), as well as to emissions (Lohman et al., 2008) has been extensively tested. These studies showed the strong impact of the choice of reactions and rate constants, as well as the impact of anthropogenic, natural and re-emissions on the global distribution of mercury in the atmosphere and stress the need for further research in the field of mercury chemistry, as well as in observations, emission inventories and hence model development.

To date, only the GRAHM (Global/Regional Atmospheric Heavy Metals) model (Dastoor and Larocque, 2004) is run in a directly coupled online mode with respect to meteorology. This model incorporates a variable grid resolution, and proved its ability to represent seasonal variability and the latitudinal gradient of mercury concentrations. No ozone photochemistry is modelled in GRAHM, ozone fields are instead received from monthly averaged MOZART (Horowitz et al., 2003) simulations. Within the complex mercury chemistry mechanism, oxidation by halogen species in the marine boundary layer and polar regions is included.

The newly developed model ECHMERIT, that is presented in the following is designed to combine the advantages of an online-coupling approach for atmospheric chemistry and transport modelling with a rather complex tropospheric chemistry and mercury chemistry description, suitable for global scale issues and flexible enough to be run in low to high resolution.

\section{Model description}

ECHMERIT is a fully coupled model, based on the Atmospheric General Circulation Model ECHAM5, and a MERcury chemistry module, developed at the Institute for Atmospheric Pollution of the Italian National Research Council (CNR-IIA) in Rende, ITaly.

\subsection{Atmospheric physics}

The atmospheric physics part of the global-scale model ECHMERIT is based on the fifth generation global climate model ECHAM5, which is developed and maintained at the Max-Planck Institute for Meteorology in Hamburg/Germany. ECHAM5 has been widely used to investigate atmospheric responses to various greenhouse-gas emission scenarios, and model performance has been extensively tested (Roeckner et al., 2003, 2006). A flexible nudging routine that is implemented in ECHAM5 enables the model to be run under real meteorological conditions for long-term simulations, nudging the model results to global reanalyses.

The basic prognostic variables of ECHAM5 are vorticity, divergence, temperature, logarithm of surface pressure and the mixing ratios of the various moisture components (like cloud water, rain water, cloud ice).

Shortwave radiation is calculated in a $2 \mathrm{~h}$ time step, for four spectral bands, one for visible and UV range and three for the near infrared. It includes an annual, as well as a diurnal cycle of solar forcing. Absorption due to water vapor and ozone are taken into account, as well as absorption due to $\mathrm{CO}_{2}, \mathrm{~N}_{2} \mathrm{O}, \mathrm{CO}, \mathrm{CH}_{4}$ and $\mathrm{O}_{2}$ as uniformly mixed gases. Scattering due to aerosols following the Mie-theory using idealized distributions of cloud ice and droplets and Rayleigh scattering are considered as well.

Gridscale cloud water content and cloud ice content are calculated from the respective budget equation, including transport of cloud water and a simplified representation of microphysical processes such as condensation, evaporation, formation of cloud droplets through coalescence, and sedimentation of ice crystals. Sub-gridscale cloud formation is also parameterized, dependent on fluctuations in total water content. The bulk mass flux scheme of Tiedtke (1989) with modifications after Nordeng (1994) is used to represent convective mass fluxes. Deep, mid level and shallow convection are considered. Organized entrainment is calculated from buoyancy, organized detrainment is computed from a spectrum of clouds detraining at different heights. Cloud water detrainment in the upper part of the convective updrafts is a source term in the stratiform cloud water equations. For deep convection an adjustment-type closure is used, which relates the cloud base mass flux to convective instability.

A parameterization for the representation of sub-gridscale orographic effects on atmospheric dynamics following Lott and Miller (1997) is included.

The soil and land surface model comprises the budgets of soil heat and water, snow cover and the heat budget of land ice. It takes into consideration the stomatal control of surface evapotranspiration through vegetation, interception, and the dependence of the sensible heat flux on snow coverage in a highly parametrized form. Major land surface properties are given as fractional values with respect to the forest, sea, snow and sea-ice fraction of a grid cell. The land-surface parameters were derived from Hagemann (2002). 


\subsection{Transport}

In the base model ECHAM5 a tracer transport routine is already implemented, for passive tracer variables, as well as water vapour. Tracers are transported through advection, convection and vertical diffusion. For transport due to advection the flux-form semi-Lagrangian advection scheme of Lin and Rood (1996) was chosen. This tracer transport scheme is a semi-Lagrangian extension of a flux-form scheme. It ensures local and global mass conservation and preserves linear tracer correlations.

The scheme of Tiedtke (1989) and Nordeng (1994), as implemented in ECHAM5 is used to calculate convective mass transport. A mass flux correction had to be implemented in ECHMERIT, because negative mixing ratios can occur in the case of strong gradients in the convective transport calculation. This especially happens in the lowest model layers, near source regions and affects most of all species with low background values but relatively large emissions. The implemented correction is strictly mass conserving and positive definite. In case net fluxes out of a grid cell exceed the available tracer mass within that cell, the fluxes are restricted to the maximum value of the available tracer as described in the following.

Mass fluxes that contribute to the updating of tracer tendencies after the calculation of convective fluxes of a single grid cell in level k are: $F_{\text {up }}^{k}$ and $F_{\text {up }}^{k+1}$, the convective updraft fluxes out of the respective layer and entering from the layer below and $F_{\text {down }}^{k}$ and $F_{\text {down }}^{k+1}$ the downdraft from the layer above and to the layer below.

The calculation of mass flux correction is performed successively from the lowest layer to the top layer in such a way that only the respective fluxes that enter and leave a cell at the top boundary are taken into consideration for correction within one grid cell. First at the end of the convection routine, the new tracer tendencies are calculated. In case the transported tracer mass exceeds the available tracer mass of a grid cell, the correction scheme is applied. With $T M$, the excessive tracer mass flux, the correction factor $(C R)$ is therefore calculated as:

$C R=\frac{T M}{\left(F_{\mathrm{up}}^{k}+F_{\text {down }}^{k}\right)}$

This correction factor is then used to calculated the corrected mass fluxes $F$ new.

$$
\begin{aligned}
& F \text { new }_{\text {up }}^{k}=F_{\text {up }}^{k} \times C R \\
& F \text { new }_{\text {down }}^{k}=F_{\text {down }}^{k} \times C R
\end{aligned}
$$

Fluxes that enter and exit the cell at the lower boundary are then updated accordingly and correction for the successive layer is continued if necessary. This scheme does not only make sure that the values are restricted to non-negative tracer concentrations, which could be also achieved by a simple cut-off of negative values, but also conserves the tracer mass of the respective model column. Nevertheless this is a relatively simple approach, which will in future model development be replaced by a more complex correction scheme such as that proposed for the Tiedtke-scheme by Brinkop and Sausen (1997).

In ECHMERIT the 26 species listed in Table 1 are transported and deposited. $\mathrm{Hg}^{\mathrm{II}}(\mathrm{aq})$ is a lumped species including all aqueous-phase mercury species present in the chemistry mechanism of ECHMERIT. For transport calculation these species are all lumped to the one species $\operatorname{Hg}^{\mathrm{II}}(\mathrm{aq})$. After transport and deposition, before the next chemistry calculation all present $\mathrm{Hg}^{\mathrm{II}}(\mathrm{aq})$ is transferred to $\mathrm{Hg}^{++}(\mathrm{aq})$ which then complexes rapidly with available ligands. When a grid cell in the next time step turns out to have a very low water content and hence only gas-phase chemistry will be calculated, the contained $\mathrm{Hg}^{\mathrm{II}}(\mathrm{aq})$ is assumed to be solid and is not subject to chemical processes, but to transport. If it later enters a "wet" grid cell it is again scavenged to take part in aqueous phase chemistry.

\subsection{Chemistry}

A wide range of different chemistry mechanisms exist in atmospheric chemistry modelling, with a great variety of complexity. Due to the largely different lifetimes of the chemical species involved, the numerical integration of these chemistry mechanisms results in highly coupled, extremely stiff non-linear systems of ordinary differential equations that require major computational effort to solve. Therefore, for application in a global atmospheric pollution and transport study it is not feasible to choose a detailed mechanism including a too large number of chemical species and reactions. Instead, in most commonly applied coupled meteorologychemistry, but also in chemical transport models the chemical mechanisms incorporate lumped chemical species to represent various species with similar lifetimes and/or chemical behaviour.

The chemistry module in ECHMERIT treats gas phase reactions, aqueous phase reactions, exchange of compounds between the aqueous and gas phases and photolysis reactions all in one overall chemical mechanism. The module was prepared using the Kinetic Pre-Processor (version 2.1) (Damian et al., 2002).

The gas phase chemical mechanism is based on the CBM$\mathrm{Z}$ mechanism (Zaveri and Peters, 1999). The CBM-Z mechanism is a follow-up to the CBM-IV mechanism, with revised inorganic and peroxide chemistry, that was specifically optimised to be suitable for longer temporal and larger spatial scales than was originally envisaged for CBM-IV. To achieve that purpose some longer-lived species and their intermediates were included, to provide a better representation of longrange transport of air pollutants.

The tropospheric aqueous phase mechanism is derived from MECCA (Sander et al., 2005) and treats $\mathrm{O}_{\mathrm{x}}, \mathrm{HO}_{\mathrm{x}}, \mathrm{NO}_{\mathrm{x}}$, $\mathrm{NH}_{3}, \mathrm{CO}_{2}$ and $\mathrm{SO}_{\mathrm{x}}$ chemistry. 
In the model the exchange of soluble compounds between the gas and aqueous phases is included as a forward and backward reaction. Equilibrium between the two phases is not assumed. The same approach is used for aqueous phase equilibria. The rate of uptake of a soluble gas is described by a mass transfer coefficient using the approach of Schwartz (1986):

$k_{m t}=\left(\frac{r^{2}}{3 D_{g}}+\frac{4 r}{3 \bar{v} \alpha}\right)^{-1}$

where $k_{m t}$ is the mass transfer coefficient in $\left[\mathrm{s}^{-1} \mathrm{~m}_{\text {air }}^{3} \mathrm{~m}_{\mathrm{aq}}^{-3}\right]$, $r$ is the mean droplet radius, $D_{g}$ the gas phase diffusivity, $\bar{v}$ is the mean molecular velocity and $\alpha$ is the accommodation coefficient. The rate of uptake is then proportional to the mass transfer coefficient and the liquid water content and how far the aqueous phase concentration is from equilibrium as defined by the Henry's Law constant (Sander, 1999). The Henry's law constant for $\mathrm{HgO}$ and other oxidised mercury compounds was chosen to be the same as for $\mathrm{HNO}_{3}$ due to the similar solubility of oxidised mercury compounds and $\mathrm{HNO}_{3}$, following the same strategy as in the CAMx model (CAMx, 2006).

The general tropospheric chemistry equations and equilibria that are based on the CBM-Z and the MECCA mechanisms and the respective references for chosen rate constants are summarized in the supplementary material of this publication (see http://www.geosci-model-dev.net/2/175/2009/ gmd-2-175-2009-supplement.zip).

For calculation of the rate constants for photolysis reactions, the Fast-J photolysis mechanism (Wild et al., 2000) was included. The photolysis routine is called and photolysis rate constants are updated every chemistry time step.

Due to the interest in $\mathrm{Hg}$ as a global pollutant, its gas phase chemistry in the atmosphere has recently been the subject of much study. The low vapour pressure of elemental $\mathrm{Hg}$ and the fact that oxidised $\mathrm{Hg}$ compounds are solids at room temperature lead to a number of experimental difficulties when attempting to determine reaction rate constants. There is some debate still as to whether certain oxidation reactions, particularly those which would lead to the formation of $\mathrm{HgO}$ actually occur in the gas phase under atmospheric conditions at all. It is possible that reactions between $\mathrm{Hg}$ and $\mathrm{OH}$ and between $\mathrm{Hg}$ and $\mathrm{O}_{3}$ would require the presence of a surface (Hynes et al., 2008; Friedli et al., 2008a).

The reaction products of the gas phase oxidation of $\mathrm{Hg}$ have not been definitively identified in reaction rate studies, nor have they been isolated in the atmosphere itself. The common term used to describe oxidised gas phase mercury compounds is Reactive Gaseous Mercury (RGM) which is operationally defined. Compounds collected on a $\mathrm{KCl}$ (potassium chloride) denuder usually over a period of two or four hours are then thermally reduced to elemental mercury which is detected using CVAFS (Cold Vapor Atomic Fluorescence Spectrophotometry). In modelling studies the
Table 1. Transported chemical species in ECHMERIT.

\begin{tabular}{|c|c|}
\hline & Chemical Species \\
\hline $\mathrm{CO}$ & carbon monoxide \\
\hline $\mathrm{Hg}^{0}$ & gaseous elemental mercury \\
\hline $\mathrm{HgO}$ & oxidised mercury \\
\hline $\mathrm{O}_{3}$ & ozone \\
\hline $\mathrm{NH}_{3}$ & ammonia \\
\hline ANOL & ethanole and higher alcohols \\
\hline $\mathrm{HgCl}_{2}$ & mercury dichloride \\
\hline $\mathrm{C}_{2} \mathrm{H}_{6}$ & ethane \\
\hline TOL & toluene \\
\hline XYL & xylene \\
\hline $\mathrm{CH}_{3} \mathrm{OH}$ & methanol \\
\hline $\mathrm{SO}_{2}$ & sulfur dioxide \\
\hline ETH & ethene \\
\hline PAR & paraffin carbon \\
\hline OLET & terminal olefin carbons \\
\hline AONE & acetone \\
\hline OLEI & internal olefin carbons \\
\hline ISOP & isoprene \\
\hline ALD2 & acetaldehyde \\
\hline $\mathrm{HCHO}$ & formaldehyde \\
\hline $\mathrm{HNO}_{3}$ & nitric acid \\
\hline NO & nitric oxide \\
\hline $\mathrm{NO}_{2}$ & nitrogen dioxide \\
\hline $\mathrm{Hg}_{\mathrm{p}}$ & particulate mercury \\
\hline $\mathrm{Hg}^{\mathrm{II}}(\mathrm{aq})$ & lumped divalent acqueous phase $\mathrm{Hg}$ \\
\hline
\end{tabular}

products of the reactions with e.g. $\mathrm{O}_{3}, \mathrm{OH}$ and $\mathrm{H}_{2} \mathrm{O}_{2}$ are generally assumed to be either all particulate or all gas phase. The effects of these assumptions on the modelled RGM concentrations in the Mediterranean MBL assuming either solid or gas phase products has been investigated and compared to measured RGM concentrations using a box model (Hedgecock et al., 2005). In this study it was found that measured RGM in the MBL was best represented either by the slower (Hall, 1995) rate constant for $\mathrm{O}_{3}+\mathrm{Hg}$ and assuming the oxidation product to be in the gas phase, or by using the more rapid rate constant (Pal and Ariya, 2004) and assuming that the product was solid, and therefore did not contribute to the RGM concentration. The faster rate for the $\mathrm{O}_{3}+\mathrm{Hg}$ reaction is not generally used in global, hemispheric or regional models as it becomes difficult to reproduce the uniformity of the distribution of $\mathrm{Hg}^{0}$ in the absence of known competing reduction reactions.

The gas phase reactions of $\mathrm{Hg}$ which have been added to the CBM-Z mechanism include those with $\mathrm{O}_{3}, \mathrm{OH}, \mathrm{H}_{2} \mathrm{O}_{2}$, $\mathrm{HCl}, \mathrm{NO}_{3}$ and $\mathrm{Br}$. The reactions with $\mathrm{Br}$ have been included for future modelling and require a $\mathrm{Br} / \mathrm{BrO}$ climatology. This is not yet included in the model. ECHMERIT in line with other global $\mathrm{Hg}$ models uses the Hall (1995) value for the $\mathrm{Hg}+\mathrm{O}_{3}$ reaction, and following the discussion above, the oxidised products are assumed to be all in the gas phase. These products are - due to a relatively high solubility expressed through the Henry's law constant - readily scavenged in the presence of liquid water and in the following subject to dry, 
Table 2. Gas phase mercury chemistry reactions and equilibria included in ECHMERIT, following (a) Hall (1995), (b) Pal and Ariya (2004), (c) Tokos et al. (1998), (d) Sommar et al. (2001), (e) Hall and Bloom (1993), (f) Ariya et al. (2002), (g) Sommar et al. (1997).

\begin{tabular}{lrc}
\hline Reaction & $\mathrm{k}$ or K $(298 \mathrm{~K})$ & Reference \\
\hline $\mathrm{Hg}^{0}+\mathrm{O}_{3} \rightarrow \mathrm{HgO}$ & $3.0 \times 10^{-20} \mathrm{~cm}^{3} \mathrm{molec}^{-1} \mathrm{~s}^{-1}$ & (a) \\
$\mathrm{Hg}^{0}+\mathrm{O}_{3} \rightarrow \mathrm{HgO}$ & $7.5 \times 10^{-19} \mathrm{~cm}^{3} \mathrm{molec}^{-1} \mathrm{~s}^{-1}$ & (b) \\
$\mathrm{Hg}^{0}+\mathrm{H}_{2} \mathrm{O}_{2} \rightarrow \mathrm{HgO}$ & $8.5 \times 10^{-19} \mathrm{~cm}^{3} \mathrm{molec}^{-1} \mathrm{~s}^{-1}$ & (c) \\
$\mathrm{Hg}^{0}+\mathrm{OH} \rightarrow \mathrm{HgO}$ & $8.7 \times 10^{-14} \mathrm{~cm}^{3} \mathrm{molec}^{-1} \mathrm{~s}^{-1}$ & (d) \\
$\mathrm{Hg}^{0}+\mathrm{HCl} \rightarrow \rightarrow \mathrm{HgCl}$ & $1 \times 10^{-19} \mathrm{~cm}^{3} \mathrm{molec}^{-1} \mathrm{~s}^{-1}$ & (e) \\
$\mathrm{Hg}^{0}+\mathrm{Br} \rightarrow \mathrm{HgBr}$ & $3.2 \times 10^{-12} \mathrm{~cm}^{3} \mathrm{molec}^{-1} \mathrm{~s}^{-1}$ & (f) \\
$\mathrm{Hg}^{0}+\mathrm{NO}_{3} \rightarrow \mathrm{HgO}+\mathrm{NO}_{2}$ & $4.0 \times 10^{-15} \mathrm{~cm}^{3} \mathrm{molec}^{-1} \mathrm{~s}^{-1}$ & (g) \\
\hline
\end{tabular}

as well as wet deposition to a much larger amount than elemental mercury with its low reactivity and solubility.

To the MECCA aqueous phase mechanism, mercury oxidation by $\mathrm{O}_{3}, \mathrm{OH}$ and $\mathrm{HOCl} / \mathrm{OCl}^{-}$, complexation with $\mathrm{OH}^{-}$, $\mathrm{SO}_{3}^{--}$, and $\mathrm{Cl}^{-}$, and reduction via the dissociation of $\mathrm{HgSO}_{3}$ have been added. Many models include the reduction of aqueous phase $\mathrm{Hg}^{\mathrm{II}}$, independent of speciation, by dissolved $\mathrm{HO}_{2}$ in a two step reaction which proceeds via $\mathrm{Hg}^{\mathrm{I}}$ (Pehkonen and Lin, 1998), however the validity of this reduction mechanism has been called into question because the $\mathrm{Hg}^{\mathrm{I}}$ formed in the first step of the reaction would be rapidly re-oxidised by dissolved $\mathrm{O}_{2}$ (Gårdfeldt and Jonsson, 2003). This reaction has therefore been excluded.

The rate constants chosen from the literature for gas, as well as aqueous-phase reactions used in ECHMERIT are summarized in Tables 2 and 3. For a discussion of the relative merits of one rate determination over another the reader is referred to chapters 14 and 15 of the interim report of the UNEP Global Partnership on Atmospheric Mercury Transport and Fate Research (Hynes et al., 2008; Friedli et al., 2008a). No atmospheric gas phase reduction reactions are known for $\mathrm{Hg}$ compounds although $\mathrm{SO}_{2}$ and $\mathrm{CO}$ have been postulated as possible reductants (Vijayaraghavan et al., 2008; Pongprueksa et al., 2007).

The chemistry mechanism implemented in ECHMERIT includes altogether 121 chemical species and represents gas, as well as aqueous-phase chemistry, with a total number of 288 chemical reactions. No stratospheric chemistry is included. To solve the chemical ODE system the variable order stiff extrapolation SEULEX solver, as described in Sandu and Sander (2006) was found to produce reasonable results, and to be more stable than the Rosenbrock solvers of 2 nd and 3rd order that were also tested. In order to save computational time and to avoid model instabilities for grid cells with a low water content, ECHMERIT distinguishes between wet and dry chemistry in a way that wet chemistry is only called in case of cloud water content exceeding a specific pre-defined threshold value. Therefore in the present model version a minimum value of $10^{5} \mathrm{\mu g} \mathrm{m}^{-3}$ for running aqueousphase chemistry, according to Jacobson (1999) was set.

\subsection{Deposition}

\subsubsection{Gaseous dry deposition}

For gaseous dry deposition, within ECHMERIT an approach similar to that described by Kerkweg et al. (2006) is used, which applies the big leaf approach used in ECHAM3 and ECHAM4 (Ganzeveld and Lelieveld, 1995; Ganzeveld et al., 1998, 2006), taking into consideration bulk properties of the respective surfaces, without accounting for removal processes occuring in different layers of the canopy. Deposition velocities are calculated from turbulent transfer, vegetation activity and uptake rates on soil, water and snow/ice. Generally the scheme is based on the commonly applied approach first described by Wesely and Hicks (1977).

Thereafter the deposition velocity $v_{d}$ is calculated using the parallel resistances approach with $R_{a}$ the aerodynamic resistance, $R_{b}$, the boundary layer resistance, and the surface resistance $R_{s}$. The calculation of these resistances generally follows Kerkweg et al. (2006).

In ECHMERIT a scaling of all species resistances to those of $\mathrm{O}_{3}$ and $\mathrm{SO}_{2}$ as in Wesely (1989) is applied and the calculated resistances depend on the solubility and reactivity of the respective species. This makes the scheme easily extendible to other chemical species. Basic resistance values for $\mathrm{O}_{3}$ and $\mathrm{SO}_{2}$ are taken from Kerkweg et al. (2006). The partitioning of land grid cells into fractions of snow/ice, bare soil, water/wet skin and vegetation, that is already implemented in ECHAM5 is taken into account within the calculation of deposition velocities. Surface resistance for vegetated land surfaces is, among other things a function of leaf resistance, which is directly dependent on stomata uptake, that is already calculated within ECHAM5, and depends on photosythetically active radiation (PAR) and the available water in the root zone (Sellers et al., 1986). As for land gridcells, aerodynamic, boundary layer and surface resistances are calculated separately and weighted according to the respective fractions of water and sea ice/snow, over the ocean area. The grid-average deposition velocities are calculated as the areaweighted average of the deposition velocities for each subgrid fraction. Unlike in the original Wesely approach, no landuse classification is used, as this is not easily derived from ECHAM5. Instead the available landuse dependent values such as LAI, roughness length and stomata resistance are directly transferred from ECHAM5 to the deposition module. The dry deposition scheme is applied to all transported gaseous species.

\subsubsection{Particulate dry deposition and sedimentation}

With respect to $\mathrm{Hg}$ associated with aerosols, ECHMERIT distinguishes between $\mathrm{Hg}$ associated with particulate matter that is directly emitted to the atmosphere from anthropogenic sources, and the $\mathrm{Hg}$ associated with particulate matter that is left behind after the evaporation of fog, cloud 
Table 3. Aqueous phase mercury chemistry reactions and equilibria included in ECHMERIT.

\begin{tabular}{|c|c|c|}
\hline Reaction & k or K $(298 \mathrm{~K})$ & Reference \\
\hline $\mathrm{Hg}^{0}(\mathrm{aq})+\mathrm{O}_{3}(\mathrm{aq}) \rightarrow \mathrm{HgO}(\mathrm{aq})$ & $4.7 \times 10^{7} \mathrm{M}^{-1} \mathrm{~s}^{-1}$ & Munthe (1992) \\
\hline $\mathrm{HgO}(\mathrm{aq})+\mathrm{H}^{+}(\mathrm{aq}) \rightarrow \mathrm{Hg}^{++}(\mathrm{aq})+\mathrm{OH}^{-}(\mathrm{aq})$ & $1 \times 10^{10} \mathrm{M}^{-1} \mathrm{~s}^{-1}$ & Pleijel and Munthe (1995) \\
\hline $\mathrm{Hg}^{++}(\mathrm{aq})+\mathrm{OH}^{-}(\mathrm{aq}) \leftrightarrow \mathrm{HgOH}^{+}(\mathrm{aq})$ & $3.9 \times 10^{10} \mathrm{M}^{-1}$ & Pleijel and Munthe (1995) \\
\hline $\mathrm{HgOH}^{+}(\mathrm{aq})+\mathrm{OH}^{-}(\mathrm{aq}) \leftrightarrow \mathrm{Hg}(\mathrm{OH})_{2}(\mathrm{aq})$ & $1.6 \times 10^{11} \mathrm{M}^{-1}$ & Pleijel and Munthe (1995) \\
\hline $\mathrm{HgOH}^{+}(\mathrm{aq})+\mathrm{Cl}^{-}(\mathrm{aq}) \leftrightarrow \mathrm{HgOHCl}(\mathrm{aq})$ & $2.7 \times 10^{7} \mathrm{M}^{-1}$ & Pleijel and Munthe (1995) \\
\hline $\mathrm{Hg}^{++}(\mathrm{aq})+\mathrm{Cl}^{-}(\mathrm{aq}) \leftrightarrow \mathrm{HgCl}^{+}(\mathrm{aq})$ & $5.8 \times 10^{6} \mathrm{M}^{-1}$ & Pleijel and Munthe (1995) \\
\hline $\mathrm{HgCl}^{+}(\mathrm{aq})+\mathrm{Cl}^{-}(\mathrm{aq}) \leftrightarrow \mathrm{HgCl}_{2}(\mathrm{aq})$ & $2.5 \times 10^{6} \mathrm{M}^{-1}$ & Pleijel and Munthe (1995) \\
\hline $\mathrm{Hg}^{++}(\mathrm{aq})+\mathrm{Br}^{-}(\mathrm{aq}) \leftrightarrow \mathrm{HgBr}^{+}(\mathrm{aq})$ & $1.1 \times 10^{9} \mathrm{M}^{-1}$ & Clever et al. (1985) \\
\hline $\mathrm{HgBr}^{+}(\mathrm{aq})+\mathrm{Br}^{-}(\mathrm{aq}) \leftrightarrow \mathrm{HgBr}_{2}(\mathrm{aq})$ & $2.5 \times 10^{8} \mathrm{M}^{-1}$ & Clever et al. (1985) \\
\hline $\mathrm{Hg}^{++}(\mathrm{aq})+\mathrm{SO}_{3}^{--}(\mathrm{aq}) \leftrightarrow \mathrm{HgSO}_{3}(\mathrm{aq})$ & $2.1 \times 10^{13} \mathrm{M}^{-1}$ & Van Loon et al. (2001) \\
\hline $\mathrm{HgSO}_{3}(\mathrm{aq})+\mathrm{SO}_{3}^{--}(\mathrm{aq}) \leftrightarrow \mathrm{Hg}\left(\mathrm{SO}_{3}\right)_{2}^{--}(\mathrm{aq})$ & $1.0 \times 10^{10} \mathrm{M}^{-1}$ & Van Loon et al. (2001) \\
\hline $\mathrm{HgSO}_{3}(\mathrm{aq}) \rightarrow \mathrm{Hg}^{0}(\mathrm{aq})+$ products & $T \exp ((31.971 \times T)-12$ & Van Loon et al. (2001) \\
\hline $\mathrm{Hg}^{0}(\mathrm{aq})+\mathrm{OH}(\mathrm{aq}) \rightarrow \mathrm{Hg}^{+}(\mathrm{aq})+\mathrm{OH}^{-}(\mathrm{aq})$ & $2.0 \times 10^{9} \mathrm{M}^{-1} \mathrm{~s}^{-1}$ & Lin and Pehkonen (1997) \\
\hline $\mathrm{Hg}^{+}(\mathrm{aq})+\mathrm{OH}(\mathrm{aq}) \rightarrow \mathrm{Hg}^{++}(\mathrm{aq})+\mathrm{OH}^{-}(\mathrm{aq})$ & $1.0 \times 10^{10} \mathrm{M}^{-1} \mathrm{~s}^{-1}$ & Lin and Pehkonen (1997) \\
\hline $\mathrm{Hg}^{\mathrm{II}}(\mathrm{aq})+\mathrm{O}_{2}^{-}(\mathrm{aq}) \rightarrow \mathrm{Hg}^{+}(\mathrm{aq})+\mathrm{O}_{2}(\mathrm{aq})$ & $1.1 \times 10^{4} \mathrm{M}^{-1} \mathrm{~s}^{-1}$ & Pehkonen and Lin (1998) \\
\hline $\mathrm{Hg}^{\mathrm{II}}(\mathrm{aq})+\mathrm{HO}_{2}(\mathrm{aq}) \rightarrow \mathrm{Hg}^{+}(\mathrm{aq})+\mathrm{O}_{2}(\mathrm{aq})+\mathrm{H}^{+}(\mathrm{aq})$ & $1.1 \times 10^{4} \mathrm{M}^{-1} \mathrm{~s}^{-1}$ & Pehkonen and Lin (1998) \\
\hline $\mathrm{Hg}^{\mathrm{I}}(\mathrm{aq})+\mathrm{O}_{2}^{-}(\mathrm{aq}) \rightarrow \mathrm{Hg}(\mathrm{aq})+\mathrm{O}_{2}(\mathrm{aq})$ & fast & Pehkonen and Lin (1998) \\
\hline $\mathrm{Hg}^{\mathrm{I}}(\mathrm{aq})+\mathrm{HO}_{2}(\mathrm{aq}) \rightarrow \mathrm{Hg}^{0}(\mathrm{aq})+\mathrm{O}_{2}(\mathrm{aq})+\mathrm{H}^{+}(\mathrm{aq})$ & fast & Pehkonen and Lin (1998) \\
\hline $\mathrm{Hg}^{\mathrm{II}}(\mathrm{aq})+\mathrm{O}_{2}^{-}(\mathrm{aq}) \rightarrow \mathrm{Hg}^{+}(\mathrm{aq})+\mathrm{O}_{2}(\mathrm{aq})$ & 0 & Gårdfeldt and Jonsson (2003) \\
\hline $\mathrm{Hg}{ }^{I I}(\mathrm{aq})+\mathrm{HO}_{2}(\mathrm{aq}) \rightarrow \mathrm{Hg}^{+}(\mathrm{aq})+\mathrm{O}_{2}(\mathrm{aq})+\mathrm{H}^{+}(\mathrm{aq})$ & 0 & Gårdfeldt and Jonsson (2003) \\
\hline $\mathrm{Hg}(\mathrm{aq})+\mathrm{HOCl}(\mathrm{aq}) \rightarrow \mathrm{Hg}^{++}(\mathrm{aq})+\mathrm{Cl}^{-}(\mathrm{aq})+\mathrm{OH}^{-}(\mathrm{aq})$ & $2.09 \times 10^{6} \mathrm{M}^{-1} \mathrm{~s}^{-1}$ & Lin and Pehkonen (1999) \\
\hline $\mathrm{Hg}(\mathrm{aq})+\mathrm{ClO}^{-}(\mathrm{aq}) \rightarrow \mathrm{Hg}^{++}(\mathrm{aq})+\mathrm{Cl}^{-}(\mathrm{aq})+\mathrm{OH}^{-}(\mathrm{aq})$ & $1.99 \times 10^{6} \mathrm{M}^{-1} \mathrm{~s}^{-1}$ & Lin and Pehkonen (1999) \\
\hline $\mathrm{Hg}(\mathrm{aq})+\mathrm{HOBr}(\mathrm{aq}) \rightarrow \mathrm{Hg}^{++}(\mathrm{aq})+\mathrm{Br}^{-}(\mathrm{aq})+\mathrm{OH}^{-}(\mathrm{aq})$ & $0.279 \mathrm{M}^{-1} \mathrm{~s}^{-1}$ & Wang and Pehkonen (2004) \\
\hline $\mathrm{Hg}(\mathrm{aq})+\mathrm{OBr}^{-}(\mathrm{aq}) \rightarrow \mathrm{Hg}^{++}(\mathrm{aq})+\mathrm{Br}^{-}(\mathrm{aq})+\mathrm{OH}^{-}(\mathrm{aq})$ & $0.273 \mathrm{M}^{-1} \mathrm{~s}^{-1}$ & Wang and Pehkonen (2004) \\
\hline $\mathrm{Hg}(\mathrm{aq})+\mathrm{Br}_{2}(\mathrm{aq}) \rightarrow \mathrm{Hg}^{++}(\mathrm{aq})+2 \mathrm{Br}^{-}(\mathrm{aq})+\mathrm{OH}^{-}(\mathrm{aq})$ & $0.196 \mathrm{M}^{-1} \mathrm{~s}^{-1}$ & Wang and Pehkonen (2004) \\
\hline $\mathrm{Hg}^{0}(\mathrm{~g}) \leftrightarrow \mathrm{Hg}^{0}(\mathrm{aq})$ & $0.13 \mathrm{Matm}^{-1}$ & Schroeder et al. (1998) \\
\hline $\mathrm{HgO}(\mathrm{g}) \leftrightarrow \mathrm{HgO}(\mathrm{aq})$ & $2.69 \times 10^{12} \mathrm{Matm}^{-1}$ & Schroeder et al. (1998) \\
\hline $\mathrm{HgCl}_{2}(\mathrm{~g}) \leftrightarrow \mathrm{HgCl}_{2}(\mathrm{aq})$ & $2.75 \times 10^{6} \mathrm{Matm}^{-1}$ & Schroeder et al. (1998) \\
\hline $\mathrm{HgBr}_{2}(\mathrm{~g}) \leftrightarrow \mathrm{HgBr}_{2}(\mathrm{aq})$ & $2.75 \times 10^{6} \mathrm{Matm}^{-1}$ & Schroeder et al. (1998) \\
\hline
\end{tabular}

or rain droplets. The $\mathrm{Hg}$ associated with particulate matter which is directly emitted to the atmosphere is considered to be insoluble and is transported as a tracer species until it is either dry deposited or scavenged by cloud droplets and wet deposited. Dry deposition velocities are calculated considering both dry deposition and gravitational settling (sedimentation), according to the approach of Slinn and Slinn (1980), similar to the adaptation within the CAMx regional scale air quality model (CAMx, 2006). Dividing the assumed lognormal particle size distribution into a fixed number of size intervals, the deposition velocity is calculated for each interval and these are subsequently aggregated in a weighted mean. Parameter values for the size distribution, with a geometric mass mean diameter of $0.3 \mu \mathrm{m}$ and a geometric standard deviation of $1.5 \mu \mathrm{m}$ were taken from Pai et al. (1997). The calculation of aerodynamic resistance follows the same approach as for gaseous dry deposition, including the same distinction between types of landcover. Boundary layer resistance depends on aerosol Brownian diffusion. Finer surface structures and particle growth in areas of high relative humidity close to the surface, as proposed by Wesely and Hicks (2000) are not considered within this approach.

\subsubsection{Wet deposition}

An approach of medium complexity was chosen to calculate wet deposition of the transported chemical species. Belowcloud, as well as in-cloud scavenging are considered. This parameterization calculates the loss through wet deposition as proportional to the mixing ratios of air pollutants. The factor of proportionality, that is the scavenging rate, depends on an assumed scavenging efficiency, the total rainfall intensity (gridscale and subgridscale), cloud water content and species solubility according to Henry's law, a mean cloud or rain droplet radius and rain droplet falling velocity, according to the approach of Seinfeld and Pandis (1998), similar to the implementation described in CAMx (2006). No wet deposition is calculated for species with low solubilities (that is with a Henry's law constant of less than $100 \mathrm{Matm}^{-1}$ following Seinfeld and Pandis, 1998). From top to bottom the deposited 
gaseous species are calculated within each precipitating cell, starting with the first precipitating cloudy layer, which is defined by a cloud water content of at least $0.25 \mathrm{~g} \mathrm{~m}^{-3}$. The gas-phase scavenging rate is calculated to account for belowcloud scavenging of gaseous species. A cloud water scavenging rate for in-cloud scavenging is calculated as well and in cloudy layers the resulting overall scavenging rate is expressed through the sum of those two. For species that are already scavenged in the cloud droplets within the chemistry scheme a different approach was chosen to calculate rain-out processes. Like for transport, also within the deposition routine, all aqueous phase $\mathrm{Hg}$ species are treated as one lumped species $\left(\mathrm{Hg}_{\mathrm{aq}}^{\mathrm{II}}\right)$. These species are already resolved in cloud droplets. Assuming a relatively homogeneous distribution of mercury in the cloudy model levels and neglecting the impact that different droplet sizes have on the exchange of species between gas and aqueous phase the following approach was chosen to calculate wet deposition of already scavenged mercury species. Basically the ratio of species mass in aqueous phase and cloud water content is assumed to be equal to the ratio of wet deposited species mass and precipitation. Therefore wet deposition of $\mathrm{Hg}_{\mathrm{aq}}^{\mathrm{II}}\left(d_{\mathrm{wet}}\right)$ is calculated for each precipitating model column as

$d_{\text {wet }}=\frac{\sum_{k=c \text { low }}^{c \text { top }} C_{k}}{\sum_{k=\text { clow }}^{c \text { top }} W_{k}} \times P$

with $c$ low and $c$ top, the lowest cloudy and the highest cloudy model layer, $C_{k}$ the species mass in aqueous phase $\left[\mathrm{kgm}^{-2}\right]$ and $W_{k}\left[\mathrm{kgm}^{-2}\right]$ the cloud water content of a single layer. $P$ is the precipitation of the respective column. This calculation is performed for each column with precipitation over all cloudy model layers below the first precipitating clouds level. Consequently in every cloudy model layer the respective diminuition of $C_{k}, d_{\text {wet, } k}$ is calculated as

$d_{\text {wet }, k}=\frac{C_{k}}{\sum_{k=c \text { low }}^{\text {ctop }} W_{k}} \times P$

\subsection{Emissions}

Offline emissions included in the model were derived from the POET emission inventory (Granier et al., 2005). This inventory is an extension of the EDGAR 3 emission dataset (Peters and Olivier, 2003), with an extrapolation of certain precursors over time, and the inclusion of new, satellite based biomass burning data. Furthermore it includes biogenic emissions with adaptations from the GEIA inventories (www.geiacenter.org) and from Mueller and Brasseur (1995). Therein a detailed vegetation canopy model was used for the calculation of isoprene and terpene emissions. These emissions are lumped to species commonly needed in chemical-transport modelling activities.

Anthropogenic mercury emissions were derived form the AMAP emission inventory (Pacyna et al., 2006). These are annual emissions, which means no seasonal cycle is included in anthropogenic mercury emissions. Figure 1 illustrates these emissions, showing clearly the major source regions, that are found in the Northern Hemisphere, in East Asia, Europe and North America, and also in South Africa.

Emissions from forest fires are included in mapping an annual mean value for mercury emissions due to forest fires of $675 \mathrm{Mgy}^{-1}$ (Friedli et al., 2008b) to the spatial and temporal distribution of $\mathrm{CO}$ biomass burning emissions from the POET emissions inventory (Granier et al., 2005), as illustrated in Fig. 2. Major source regions of forest fire emissions are therefore found in Central and Western Africa, the Amazon region in South America and in Australia. Mercury emissions due to forest fires in the Southern Hemisphere might therefore be a bit overestimated, as the mercury content found in the biosphere is, after all dependent on mercury content in soils and on vegetation cover, which depends on naturally high mercury contents in geologically active zones, as well as on mercury deposited from the atmosphere, which is generally higher in the Northern Hemisphere due to higher mercury mixing ratios in the atmosphere, following higher anthropogenic emissions.

Ocean emissions are also mapped according to biogenic $\mathrm{CO}$ emissions from the ocean, assuming a global annual sum of $3000 \mathrm{Mgy}^{-1}$ of $\mathrm{Hg}$ to be emitted from the ocean. A similar approach has been chosen for $\mathrm{Hg}$ emissions due to biogenic activities and emissions from soils, with an annual sum of $1669 \mathrm{Mgy}^{-1}$, following Mason (2008). To take into account not only biological activity, but also the dependence of mercury emission from former deposition, two thirds of the emissions from soils and vegetation was mapped according to regions with high deposition rates from a previous model run. The remaining third is solely dependent on vegetational activity and hence mapped with the $\mathrm{CO}$ emission from the POET inventory as only one third of natural emissions are assumed to be free from anthropogenic influences. The sum of biogenic emissions and ocean emission is illustrated in Fig. 3. Highest emissions are therefore found from the oceans, and a minimum over desert and polar regions. A more realistic representation of natural emission is required for global mercury modelling, which can be achieved either through sophisticated approaches of online calculation of mercury emissions dependent on soil, biomass and ocean water mercury content - data that is not globally available, or through improved mercury emission inventories, also including natural emissions and their temporal variations.

The data from emission inventories are within a preprocessing step interpolated to the model grid, using the mass conserving remapping tool of the Climate Data Operators (CDO) (Schulzweida et al., 2007) and then serve as input to the simulation and are added to the chemical species concentration within each chemistry time step.

A certain fraction (20\%) of wet and dry deposition of $\mathrm{RGM}, \mathrm{Hg}_{\mathrm{aq}}^{\mathrm{II}}$ and $\mathrm{Hg}_{\mathrm{p}}$ are assumed to be directly re-emitted to the atmosphere as $\mathrm{Hg}^{0}$ over land areas, an approach similar to 

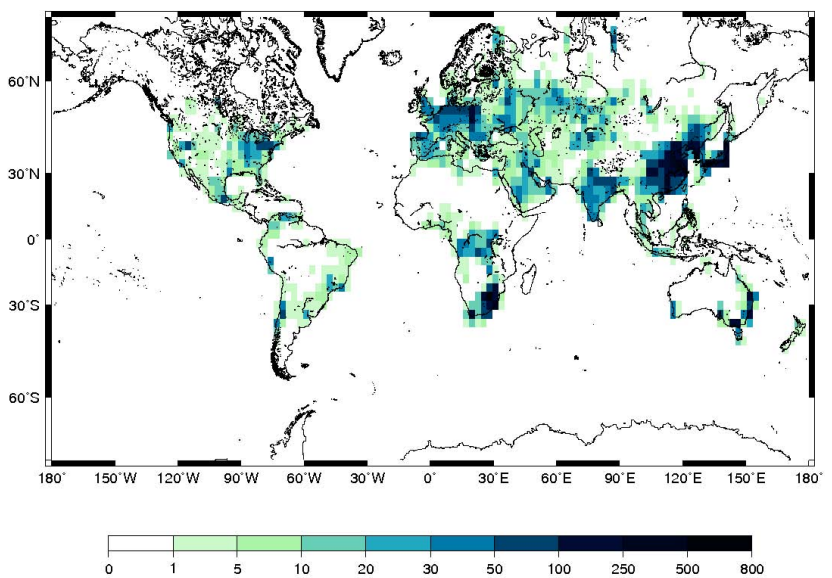

Fig. 1. Annual anthropogenic TGM emissions $\left[\mathrm{kgm}^{-2}\right]$.
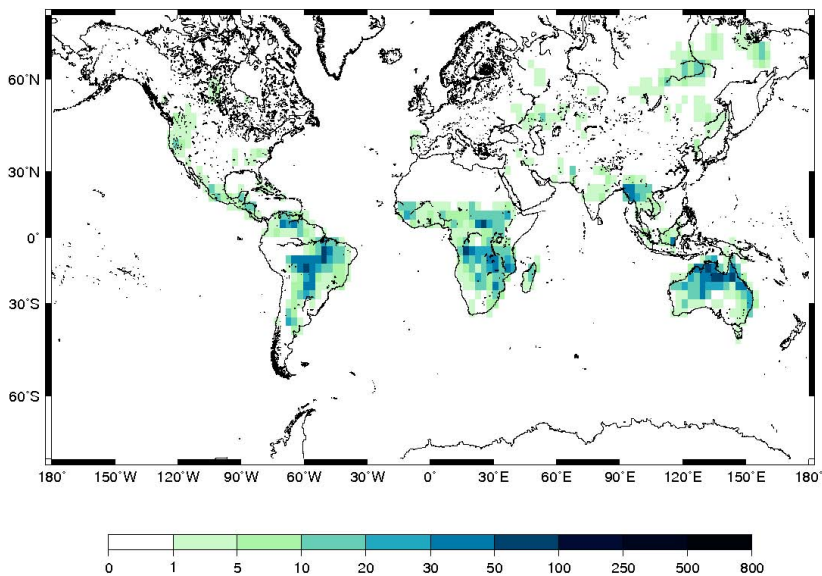

Fig. 2. Annual biomass burning elemental $\mathrm{Hg}$ emissions $\left[\mathrm{kgm}^{-2}\right]$.

the one implemented in the GEOS-chem global mercury simulations (Jaeglé et al., 2008). Re-emissions over the oceans are included within the global annual oceanic emissions and therefore no direct re-emission from the ocean is calculated.

\subsection{Model discretization}

ECHAM5 is a spectral transform model. The partial differential equations are discretized using a pseudo-spectral method. Vorticity, divergence, temperature and the logarithm of surface pressure are calculated by truncated spherical harmonics, whereas non-linear and diabatic terms, such as moisture and cloud water mixing ratios are calculated on a Gaussian grid. ECHAM5 has a flexible horizontal resolution, and has been applied in resolutions ranging from T21 (5.06 degrees) to T159 (0.75 degrees). For temporal discretization the model uses a semi-implicit leap-frog scheme, and includes a weak time filter to suppress computational modes. In the vertical ECHAM5 is discretized with a hybrid-sigmapressure system with 19 or 31 non-equidistant layers, with
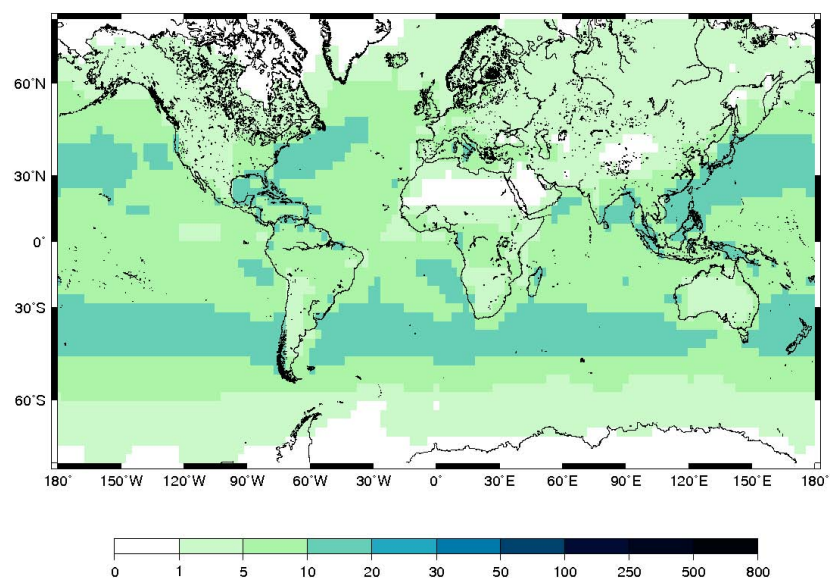

Fig. 3. Annual natural (ocean and vegetation/soil) elemental $\mathrm{Hg}$ emissions $\left[\mathrm{kgm}^{-2}\right]$.

a decreasing model resolution with height. With 19 vertical layers the lower 10-15 layers are tropospheric, the remaining are stratospheric layers. Furthermore a middle atmosphere version of ECHAM5 is available, that has an increased vertical resolution in the mid-atmosphere with 39 to 90 layers up to $0.01 \mathrm{hPa}$, which was not considered for ECHMERIT so far, as in ECHMERIT only tropospheric chemistry is included.

\subsection{Technical implementation}

The development of the ECHMERIT model took care that the structure is as modular as possible, to make it flexible and easily applicable for different studies, so that it is possible to include different deposition, emission or chemical schemes without much effort. Like the mixing ratios of water vapour, cloud water etc., the chemical species mixing ratios are defined in grid-point space and the chemical mechanism is included within the grid-point calculation routine of ECHAM5. The chemical module itself was prepared using the KPP kinetic preprocessor (Damian et al., 2002). Also in the vertical, ECHMERIT uses the same discretization as ECHAM5. Because only tropospheric chemistry is included in the model, the calculation of atmospheric chemistry is restricted to the tropospheric model layers. Generally emission, chemstry, photolysis and deposition routines are called in the same time step, as the leap-frog of the base model. To allow for a more frequent updating of photolysis rates and input of emissions, these schemes are called more frequently in low resolution model simulations (T42 and lower). To avoid negative mixing ratios that can occur in the case of strong gradients, two adaptations of the ECHAM5 transport schemes were implemented. First, the operator splitting (a first oder splitting) was constrained to be strictly sequential for the different processes of transport, deposition, emission and chemistry. Secondly, a mass-conserving flux correction 
was introduced to the convective tracer mass flux calculation, as described in Sect. 2.2.

\section{Model setup}

For the following examples of model performance and a first evaluation of ECHMERIT the model was run with the setup described below.

Roeckner et al. (2006) showed in a detailed study the sensitivity of the mean climate state simulated by ECHAM5 to horizontal and vertical resolution. Results showed that at a vertical resolution of L19 there is no improvement of model results for horizontal resolutions higher than T42. On the other hand, for T42 horizontal resolution increasing the number of vertical layers from L19 to L31 did not show any benefit either. As for this first study on model testing and validation, ECHMERIT was run in a T42 resolution, and the L19 vertical resolution was chosen. Of these 19 non-equidistant layers, the upper 4-9 (dependent on latitude) are situated within the stratosphere.

Initial and lower boundary SST were taken from the AMIP (Atmospheric Model Intercomparison Project) (Taylor et al., 1997) reanalysed monthly averaged observational sea surface temperature (SST) data. Land use characteristics, such as roughness length, leaf area index (LAI) and stomata resistance were used directly from ECHAM5.

Ozone mixing ratios from the climatology implemented in ECHAM5 (Fortuin and Kelder, 1998) was used as the initial mixing ratios and for the stratospheric model layers, where no chemistry is calculated. Some species' concentrations are set to constant values in the stratosphere $\left(\mathrm{NO}=0.05 \mathrm{nmol} / \mathrm{mol}, \mathrm{NO}_{2}=1 \mathrm{nmol} / \mathrm{mol}\right.$, $\mathrm{HNO}_{3}=3 \mathrm{nmol} / \mathrm{mol}, \mathrm{HCl}=0.6 \mathrm{nmol} / \mathrm{mol}$ ). All other variables are initialized with zero and allowed to spin up until reaching steady-state. A spin-up period of 4 years was necessary to achieve this for mercury.

The simulation period for model evaluation was the year of 2001 and included a nudging of model meteorology to ECMWF ERA40 reanalysis data.

\section{Model testing}

A complete model validation and statistical analysis is not within the scope of this first model presentation. In the following sections the plausibility of the model results and its general performance is considered, where the major focus lies on surface ozone and mercury mixing ratios, but $\mathrm{OH}$ and deposition calculation is also discussed.

\subsection{Deposition velocities}

Figures 4 , and 5 show examples of the simulated dry deposition velocity of ozone and sulfur dioxide to demonstrate the performance of the dry deposition scheme in ECHMERIT.

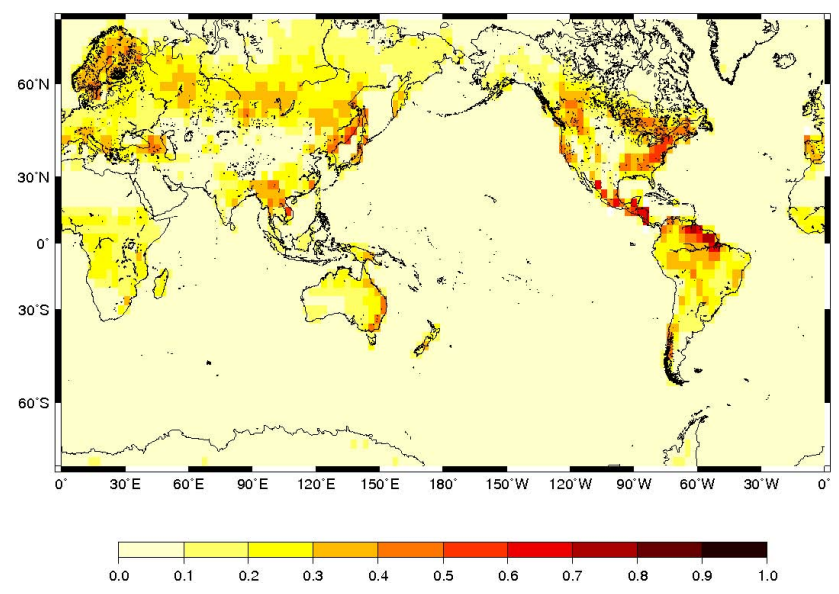

Fig. 4. Mean annual $\mathrm{O}_{3}$ dry deposition velocity $\left[\mathrm{cms}^{-1}\right]$.

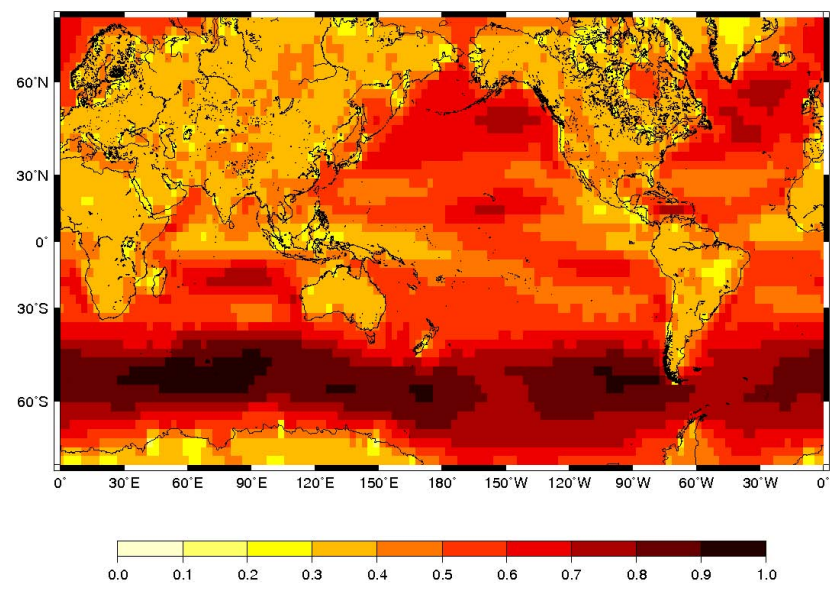

Fig. 5. Mean annual $\mathrm{SO}_{2}$ dry deposition velocity $\left[\mathrm{cms}^{-1}\right]$.

The influence of solubility (high solubility of $\mathrm{SO}_{2}$ and low solubility of $\mathrm{O}_{3}$ ) can be clearly seen. The ozone dry deposition velocity shows higher values over land than over the sea, due to its low solubility. For the $\mathrm{SO}_{2}$ dry deposition velocity the opposite is observed. Very high velocities are observed over the oceans due to the high solubility of $\mathrm{SO}_{2}$ additionally enhanced in regions with high wind speeds (especially over the Southern oceans). The $\mathrm{SO}_{2}$ deposition velocities are in good agreement with the simulation results of Ganzeveld et al. (1998). The high solubility and the high reactivity of oxidised mercury leads to a dry deposition velocity for RGM very similar to that of $\mathrm{SO}_{2}$ (Fig. 6).

\section{$4.2 \mathrm{O}_{3}$ mixing ratios}

Ozone is believed to be one of the oxidants of elemental mercury (compare Sect. 2.3). Therefore modelling ozone mixing ratios correctly, in terms of magnitude, and temporal and spatial variability is crucial for the simulation of the oxidation and subsequent removal of mercury from the atmosphere. 

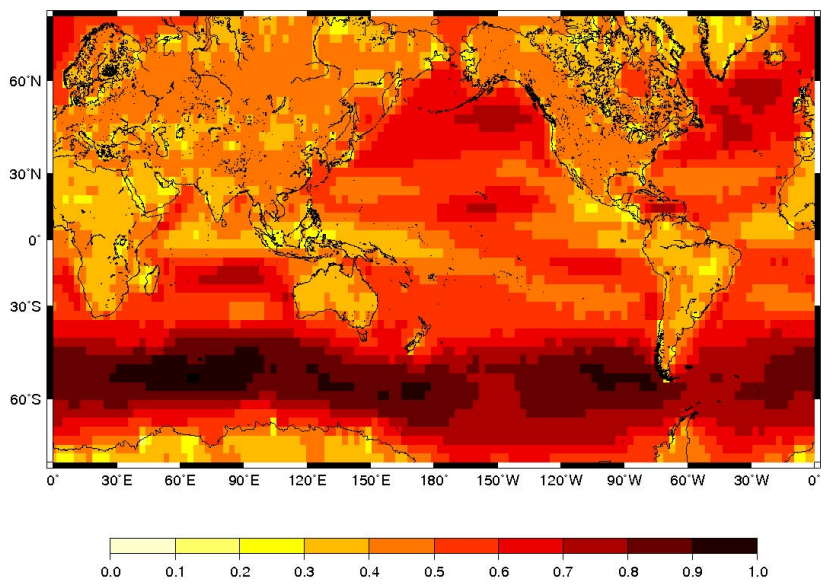

Fig. 6. Mean annual RGM dry deposition velocity $\left[\mathrm{cms}^{-1}\right]$.
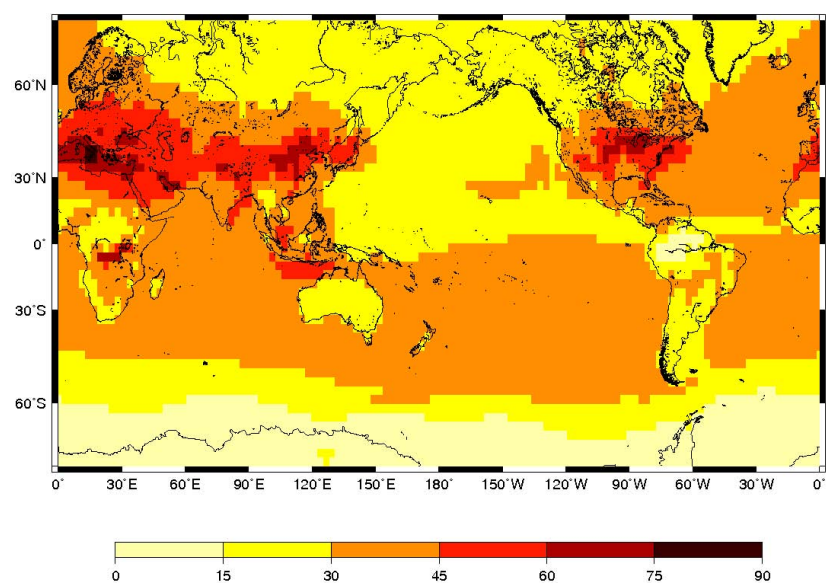

Fig. 7. Mean simulated summer (JJA) surface layer ozone mixing ratio $[\mathrm{nmol} / \mathrm{mol}]$.

Hence in a first step of model evaluation, the simulation results for ozone for the year 2001 were analyzed.

In Figs. 7 and 8 the seasonal global distributions of surface ozone for northern hemispheric summer (JJA) and winter (DJF) are illustrated. A clearly seasonally varying ozone mixing ratio with highest values (of up to $80 \mathrm{nmol} / \mathrm{mol}$ ) over the Mediterranean region and North America in the summer season (JJA) can be observed. Also high values can be observed over the East Asian emission source regions and in central Africa. These high mixing ratios in Africa during the summer period are caused by ozone precursor emissions in biomass burning plumes during the dry season. Relatively high ozone mixing ratios are observed in all seasons over the Northern Atlantic and Pacific oceans which is due to the relatively long lifetime of ozone and the transport of precursors away from source regions with the prevailing westerly winds, but also away from enhanced ozone consuming processes/species, that are found in the source regions.

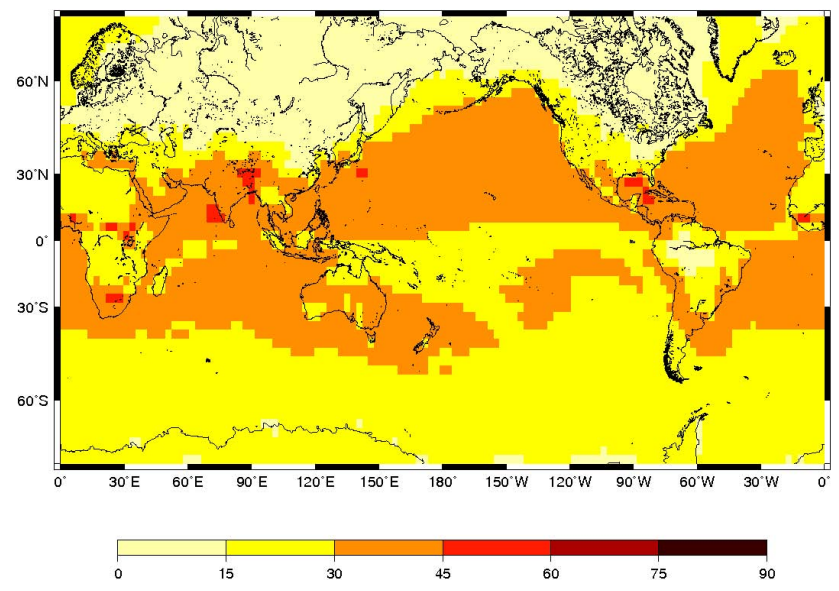

Fig. 8. Mean simulated winter (DJF) surface layer ozone mixing ratio $[\mathrm{nmol} / \mathrm{mol}]$.

In this context the high values in summer off the North American and Indian coasts are to be highlighted. These are most likely caused by the eastward transport (with the westerlies over the Atlantic and the south-western monsoonal winds over India) of precursor substances. Influenced by source regions in Western India, this can be also observed in winter over the Indian ocean, when northeasterly winds dominate.

Monthly mean ozone mixing ratios for several stations of the EMEP network are compared in Fig. 9. A good agreement with observations is achieved for mid-latitude stations. Further north the agreement, especially in springtime diminishes. Model results for the stations in the very north of Europe show somewhat poor representation of the annual ozone cycle, where winter mixing ratios are underestimated. The reasons for this are not entirely clear, but might lie in an underestimation of ozone transport from the stratosphere to the troposphere at that time of the year.

Examples of the comparison between station ozone measurements of the EMEP network and the nearest ECHMERIT gridpoint show a reasonable agreement. As demonstrated in the scatterplot (Fig. 10) ECHMERIT tends to slightly underestimate winter ozone mixing ratios and overestimate ozone mixing ratios in summer.

Figure 11 demonstrates the performance comparing monthly mean values to observations of the GAW network and hence draws a more global picture. Here it is illustrated that there is generally an underestimation in polar regions and an overestimation in the tropics. The underestimation that occurs in the subtropics and mid-latitudes can be attributed to an underestimation in the spring maximum, whereas the mid-latitudal overestimation of ozone maxima in summer that was also demonstrated in Fig. 10 can also be identified here. The frequent overestimation in the tropical regions can be also seen when looking at vertical ozone soundings. Figure 12 gives examples for ozone soundings in 

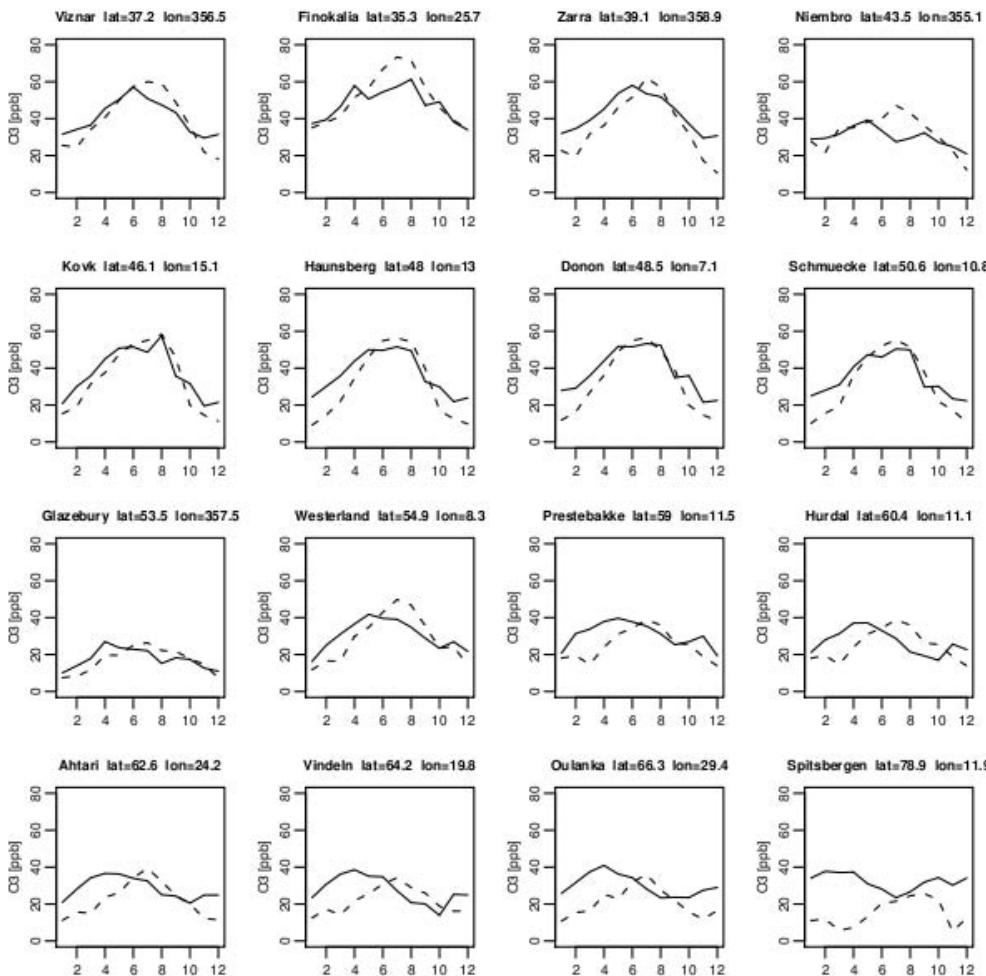

Fig. 9. Simulated vs. observed (EMEP) monthly mean ozone mixing ratio [nmol/mol] for selected observational stations, dashed: ECHMERIT, full line: EMEP observations.

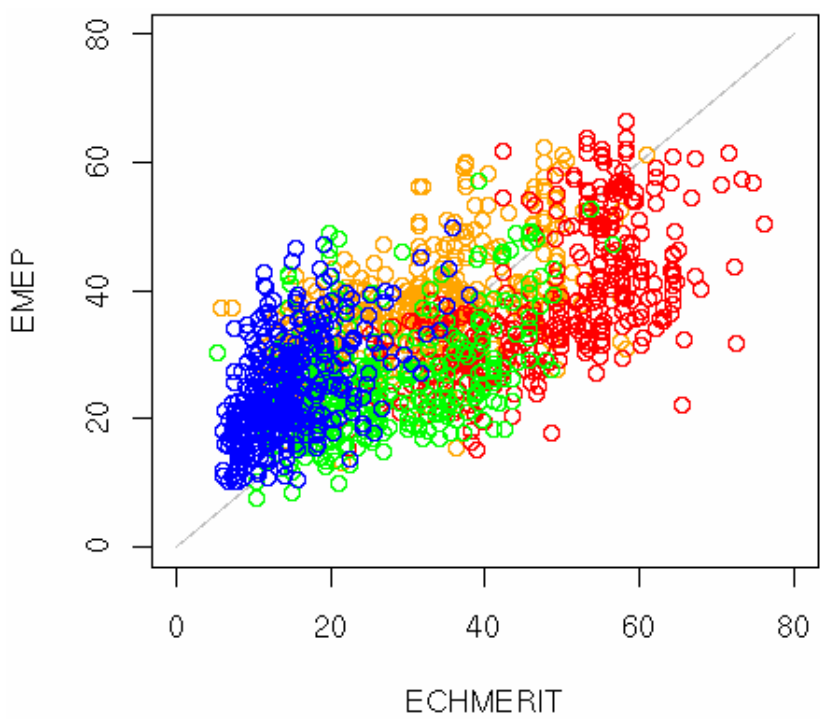

Fig. 10. Simulated vs. observed (EMEP) monthly mean ozone mixing ratio $[\mathrm{nmol} / \mathrm{mol}]$, colours mark different seasons: red=JJA, orange $=\mathrm{MAM}$, green $=\mathrm{SON}$, blue $=\mathrm{DJF}$ regions .

the tropical zone based on data from the SHADOZ experiment (Thompson et al., 2003). It could be seen that especially in low-polluted sites the model tends to overestimate ozone concentrations over the entire troposphere whereas in many other sites the model performance seems reasonable. Reasons for this have to be investigated in a following profound model validation.

\subsection{OH concentrations}

Figure 13 show latitudal mean $\mathrm{OH}$ concentrations in the troposphere. It demonstrates an $\mathrm{OH}$ maximum in midtroposphere tropical regions. Generally $\mathrm{OH}$ concentrations range from 0.1 to $2.5 \times 10^{6}$ moleculescm $^{-3}$. This is well within the range of calculated vertical $\mathrm{OH}$ distributions, as was for example demonstrated in a study of Lawrence et al. (2001), where different methods of retrieval of atmospheric $\mathrm{OH}$ concentrations were compared. Hence the tropics is one of the zones with enhanced mercury oxidation and formation of RGM.

\subsection{Hg mixing ratios}

An evaluation of model performance for mercury species was achieved considering total gaseous mercury (TGM) in the surface layer and compared to single observational station values of the EMEP observational network (http://tarantula. nilu.no/projects/ccc/emepdata.html). Figure 14 illustrates the annual mean surface TGM mixing ratios $[\mathrm{fmol} / \mathrm{mol}]$, as simulated by ECHMERIT. Higher mercury mixing ratios in 
Table 4. Statistical measures of model performance with $M_{i}$ modelled value and $O_{i}$ observed value.

\begin{tabular}{lll}
\hline name & variable & equation \\
\hline geometric mean bias & $\mathrm{MG}$ & $\exp (\overline{\ln O}-\overline{\ln M})$ \\
mean bias & $\mathrm{MB}$ & $\frac{1}{N} \sum_{i=1}^{N}\left(M_{i}-O_{i}\right)$ \\
mean absolute gross error & $\mathrm{MAGE}$ & $\frac{1}{N} \sum_{i=1}^{N}\left|M_{i}-O_{i}\right|$ \\
mean normalized gross error & $\mathrm{MNGE}$ & $\frac{1}{N} \sum_{i=1}^{N} \frac{\left|M_{i}-O_{i}\right|}{O_{i}} \times 100$ \\
geometric variance & $\mathrm{VG}$ & $\exp \left[(\ln O-\ln M)^{2}\right.$ \\
\hline
\end{tabular}

the Northern Hemisphere can be delineated, especially near source regions in Europe, North America and East Asia, where values of over $300 \mathrm{fmol} / \mathrm{mol}$ are reached. According to observations mean background concentrations of elemental mercury are between 1.5 and $1.7 \mathrm{ngm}^{-3}$ in the Northern Hemisphere and between 1.1 and $1.3 \mathrm{ngm}^{-3}$ in the Southern Hemisphere (Lindberg et al., 2007). This gradient between the hemisphere is more pronounced than in this ECHMERIT simulation where mean concentrations in Southern and Northern Hemisphere are 1.2 and $1.3 \mathrm{ngm}^{-3}$, respectively. This can be attributed to the relatively high emissions of mercury from the oceans, that make up more than half of the global annual emissions of mercury. These emissions, if mapped with the $\mathrm{CO}$ emissions from the POET emission inventory, as currently is the case in ECHMERIT, somewhat underestimate Northern Hemisphere ocean emissions because they overestimate mercury emissions from the Southern oceans especially during the Southern Hemisphere summer, due to the strong link between $\mathrm{CO}$ emissions and biological activity and because the spatial distributions of previously deposited mercury is neglected. Additionally, possibly the atmospheric lifetime of $\mathrm{Hg}$ in the Southern Hemisphere is smaller due to a higher concentrations of bromine following a higher sea-salt aerosol production in the Southern Hemisphere caused by higher wind speeds (Yang et al., 2005).

The scatterplot (Fig. 15), showing monthly mean TGM mixing ratios of all available EMEP stations compared to the modelled values at the nearest grid point demonstrate a reasonable model performance. Apart from the summer months (JJA) TGM mixing ratios tend to be underestimated in the simulation. This is, as mentioned before due to the overestimation of mercury emissions from the oceans, from soil, vegetation and biomass burning in the Southern Hemisphere, which consequently means an underestimation of mercury emission in the Northern Hemisphere, because the global annual emission sums are restricted to the predefined values, but the distribution depends basically on the one derived from $\mathrm{CO}$ emission inventories (compare Sect. 2.5). Therefore the background mixing ratios in the Northern Hemisphere are underestimated during autumn/winter.

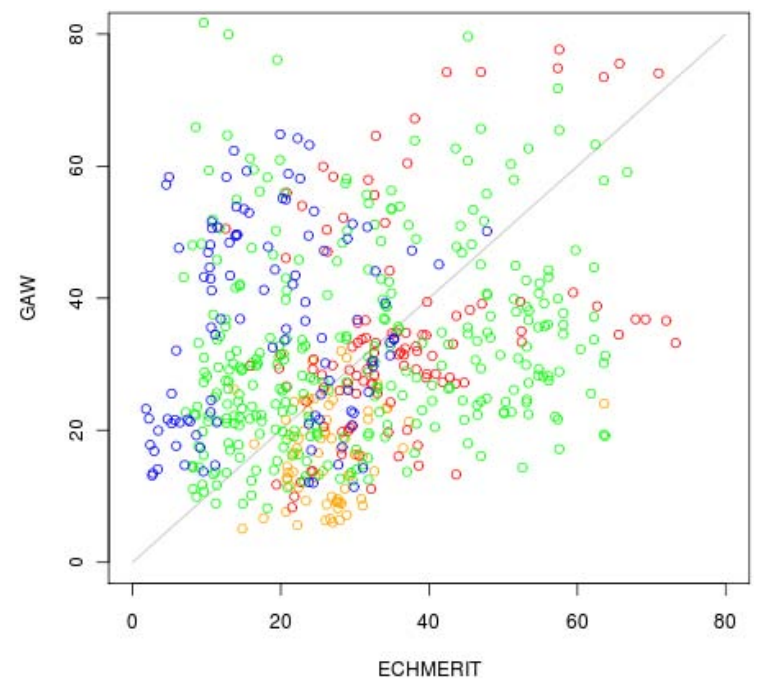

Fig. 11. Simulated vs. observed (GAW) monthly mean ozone mixing ratio [nmol/mol], colours mark different zones: red=subtropics, orange $=$ tropics, green $=$ mid-latitudes, blue=polar regions .

Table 5. Statistical measures for ozone and mercury modelling results evaluation for EMEP surface observations.

\begin{tabular}{lrr}
\hline & Ozone & TGM \\
\hline modelled mean & $30.40 \mathrm{nmol} / \mathrm{mol}$ & $161.83 \mathrm{fmol} / \mathrm{mol}$ \\
measured mean & $31.86 \mathrm{nmol} / \mathrm{mol}$ & $175.38 \mathrm{fmol} / \mathrm{mol}$ \\
modelled max & $76.34 \mathrm{nmol} / \mathrm{mol}$ & $187.57 \mathrm{fmol} / \mathrm{mol}$ \\
measured max & $66.37 \mathrm{nmol} / \mathrm{mol}$ & $213.04 \mathrm{fmol} / \mathrm{mol}$ \\
modelled min & $5.19 \mathrm{nmol} / \mathrm{mol}$ & $134.03 \mathrm{fmol} / \mathrm{mol}$ \\
measured min & $7.47 \mathrm{nmol} / \mathrm{mol}$ & $134.82 \mathrm{fmol} / \mathrm{mol}$ \\
MG & 1.14 & 1.08 \\
MB & $1.46 \mathrm{nmol} / \mathrm{mol}$ & $13.55 \mathrm{fmol} / \mathrm{mol}$ \\
MAGE & $9.72 \mathrm{nmol} / \mathrm{mol}$ & $20.22 \mathrm{fmol} / \mathrm{mol}$ \\
MNGE & $32.53 \%$ & $11.22 \%$ \\
VG & 1.23 & 1.02 \\
\hline
\end{tabular}

\subsection{Statistical measures for mercury and ozone validation}

In Table 5 some statistical measures for ozone as well as mercury are summarized. A description is given in Table 4 . Most of the measures are based on Chang and Hanna (2004). These are calculated from observational data from the EMEP network and the respective nearest gridpoints of the simulation. The mean bias (MB) and geometric mean bias (MG) are both measures to capture systematic biases of the model. These are both comparably small, but MG is a little larger for mercury $(13.55 \mathrm{fmol} / \mathrm{mol})$. Also summarized are the mean gross error (MAGE) and the normalized MAGE (MNGE) [\%] (that is normalized according to the observational mean value). The MNGE indicates a relatively smaller deviation for the mercury mixing ratios $(11 \%)$ than for ozone $(33 \%)$. 

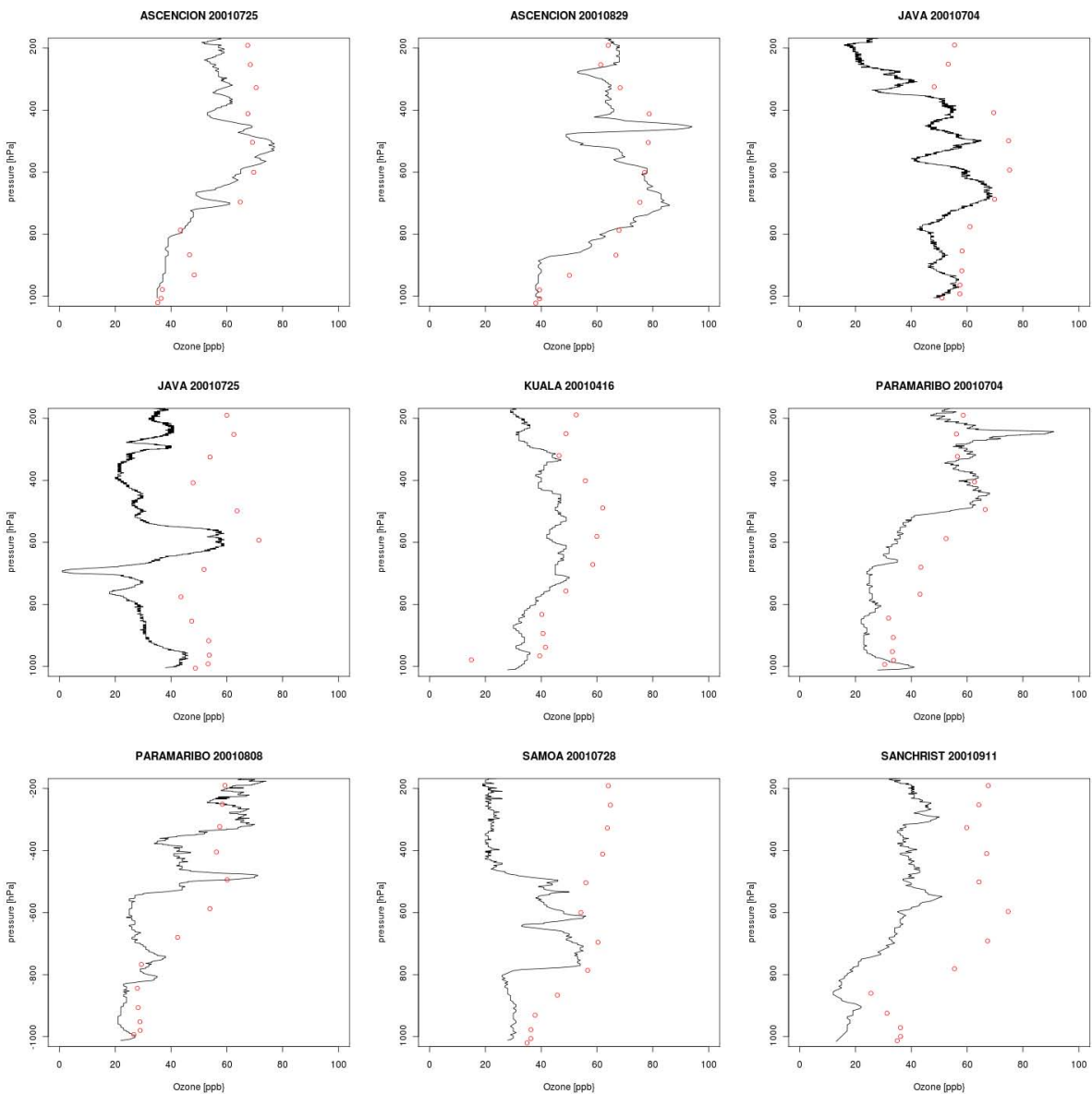

Fig. 12. Ozone soundings from the SHADOZ dataset (black line) compared to simulations (red circles), ozone mixing ratios in [nmol/mol].

This is most likely influenced by the generally higher variability of ozone that is harder to reproduce, than the variability of mercury species which is relatively smaller with respect to the background mixing ratios. In contrast to $\mathrm{MG}$, the geometric variance (VG) shows the relative scatter, which is composed of systematic, as well as random errors. These values also show satisfying results for both $\mathrm{O}_{3}$ (1.23) and TGM (1.02). Generally a satisfactory model performance is obtained from these statistical analysis of model results with respect to observation data. Nevertheless, it has to be pointed out that comparing only observational point data to the simulation values, which are representative of the mean mixing ratios in the entire grid cell cannot give a precise look at model performance, therefore model validation has to be extended in future studies.

\subsection{Mercury deposition processes}

Before wet deposition of mercury species can be evaluated it is reasonable to evaluate model performance with respect to precipitation. In Tost et al. (2006) a comparison of different convective parameterizations within the ECHAM5/MESSy modelling system was performed. Model resolution was T42 with 31 vertical layers, and therefore the obtained results cannot be completely comparable to our study, as the vertical resolution has a strong impact on strength and position of the Hadley cell and on the location of the mid-latitude westerlies as illustrated for ECHAM5 by Roeckner et al. (2006). Nevertheless the study of Tost et al. (2006) demonstrated large differences in precipitation fields due to differences in convective parameterizations, whereas simulated water vapour columns were similar and matched observations very well. Annual mean precipitation was overestimated with all convection schemes over the continents in the tropics and in the southern storm tracks. This can be verified also in this modelling study. Figure 16 demonstrates the annual simulated precipitation for the year 2001 of the ECHMERIT run. Figure 17 instead shows the rainfall over land based on the CRU (Climate Research Unit) dataset (New et al., 1999, 2000). Comparing the modelled precipitation to the CRU data reveals also an overestimation of rainfall especially in the tropical zones. Precipitation in mid-latitudes is generally within the range of observed amounts. 


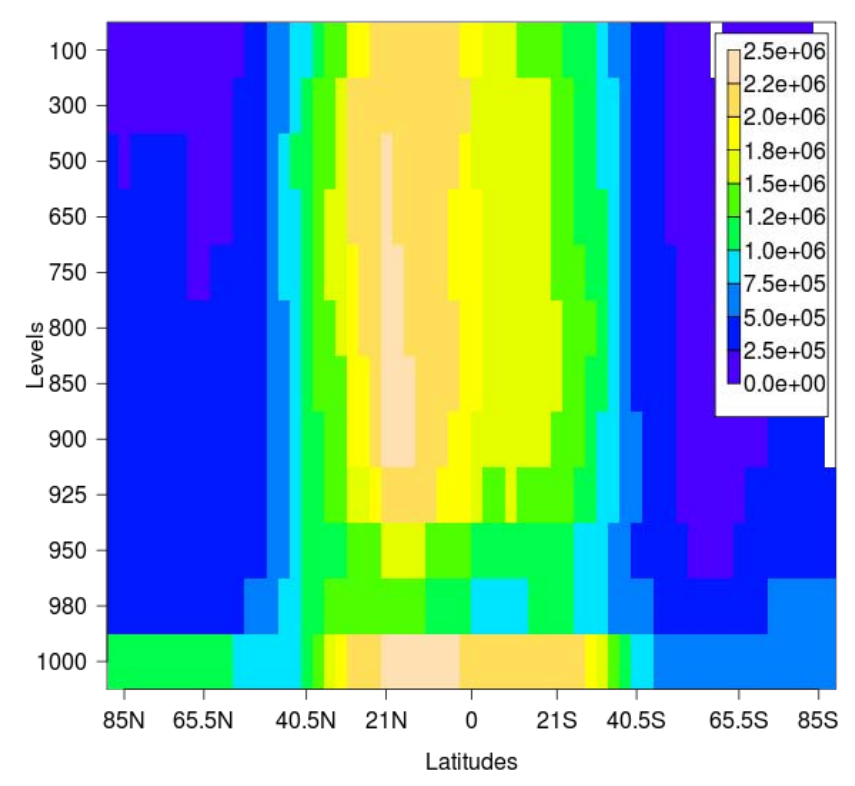

Fig. 13. Annual zonal mean $\mathrm{OH}\left[\right.$ molecules $\left./ \mathrm{cm}^{3}\right]$ distribution.
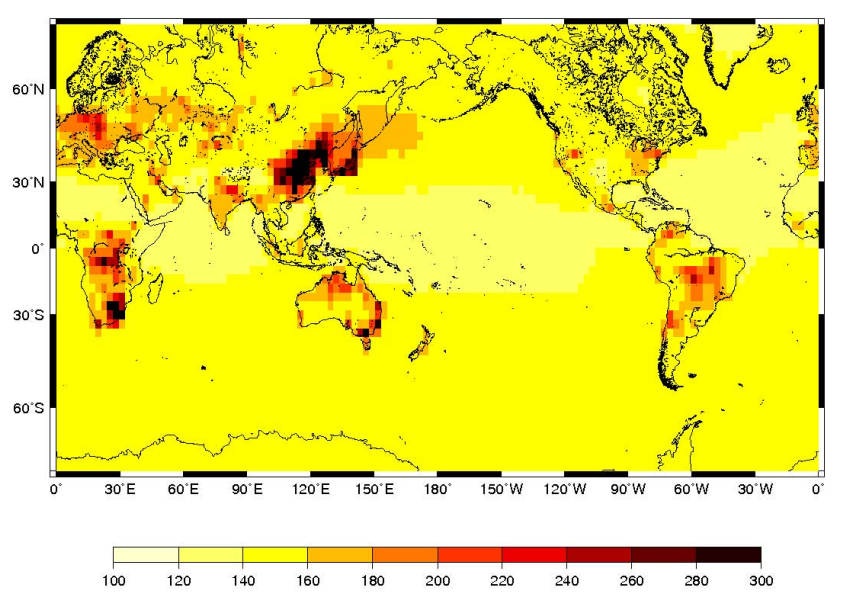

Fig. 14. Annual mean simulated surface layer TGM mixing ratio [fmol/mol].

Annual wet deposition of TGM is illustrated in Fig. 18. An obvious dependence on precipitation pattern is found, but additionally the deposition amount depends on the emission strength in source regions, which can be seen for the Southern Pacific and Indian ocean, but also for the strong sources in East Asia. Of the wet deposited mercury, 87.6\% is below-cloud scavenged RGM, whereas $12.36 \%$ is $\mathrm{Hg}^{\mathrm{II}}(\mathrm{aq})$ that rained out and was already present in cloud droplets, taking part in aqueous-phase chemistry. Wet deposition maxima over the US are found over the eastern parts of the country which is in agreement with measurements and a modelling study of Selin et al. (2007). A comparison of the model results with observational data of the MDN (Mercury Deposition Network) (Vermette et al., 1995) and EMEP mercury

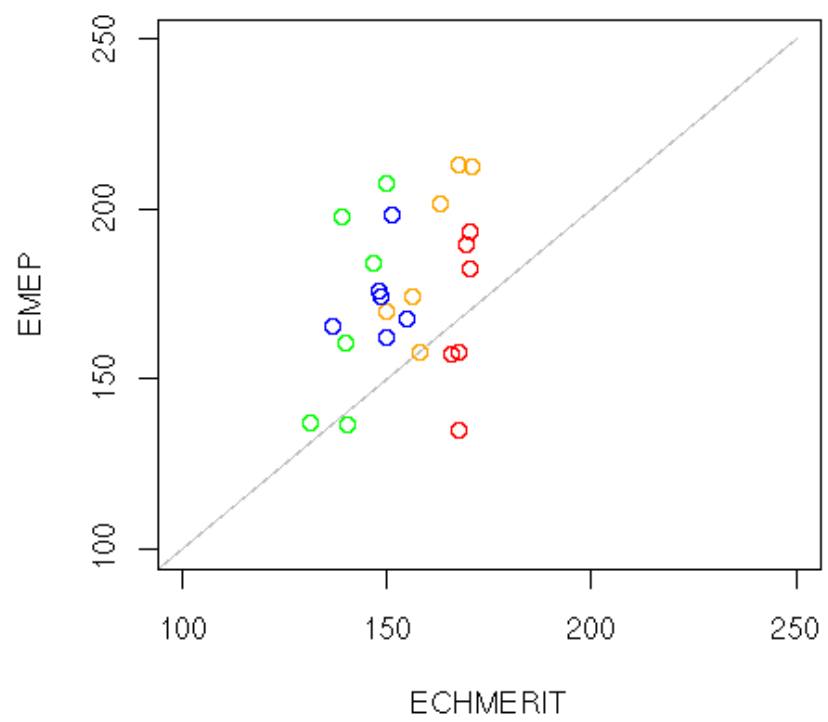

Fig. 15. Simulated vs. observed (EMEP) monthly mean TGM mixing ratio [fmol $/ \mathrm{mol}]$, colors mark different seasons: red=JJA, orange $=$ MAM, green $=S O N$, blue $=$ DJF.
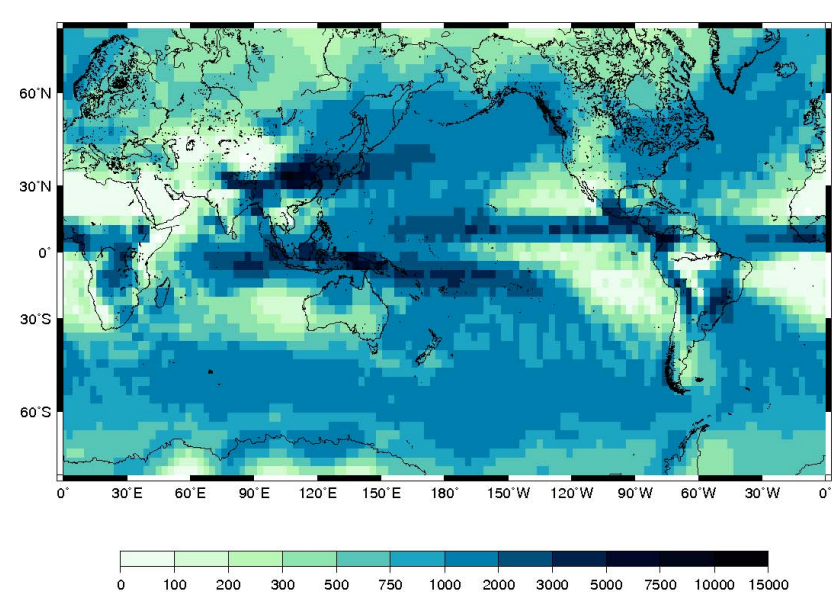

Fig. 16. Annual simulated precipitation for 2001 [mm].

wet deposition data (Fig. 19) shows a general overestimation of wet deposition in the model, but compared to the general difficulties in simulating correct precipitation amounts and distribution the results lie in an acceptable range (within an oder of magnitude or better). Anyhow comparing point measurements to modelled data of the nearest gridpoint in a coarsly resolved global model is of limited validity and has always to be taken with caution, as the value of the respective gridbox represents the mean over the grid box.

Dry deposition (Fig. 20) in this model simulation is 99.43\% RGM. Due to the very low deposition velocities for elemental mercury this is negligible. These deposition velocities are generally below $0.1 \mathrm{cms}^{-1}$ and might be underestimated, as one of the few available measurements of $\mathrm{Hg}^{0}$ 

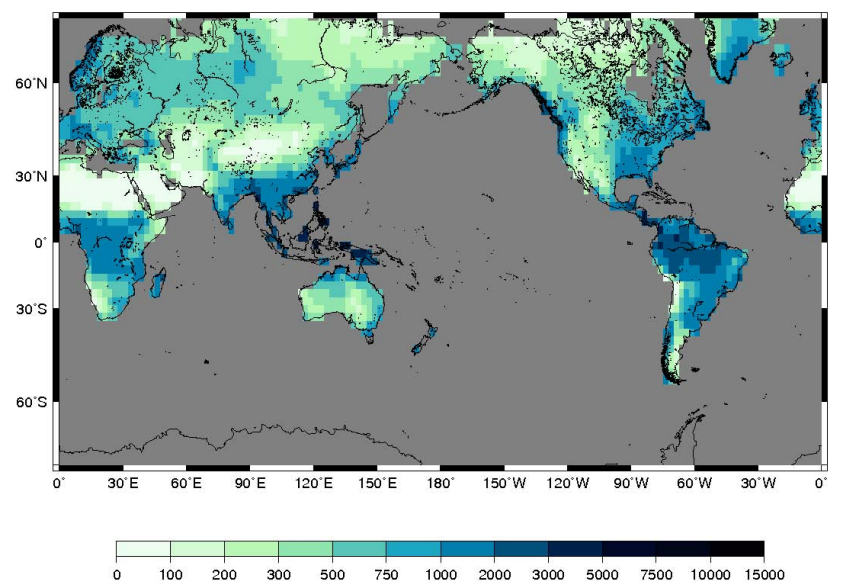

Fig. 17. Annual observed (CRU) precipitation for 2001 [mm].

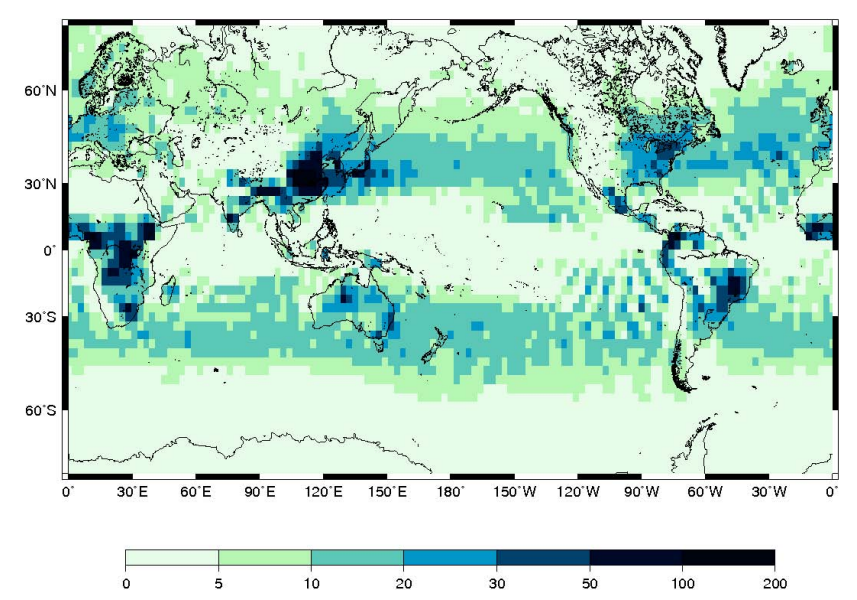

Fig. 18. Annual $\mathrm{Hg}$ wet deposition $\left[\mu \mathrm{gm}^{-2}\right]$.

deposition over vegetated mid-latitude areas showed deposition velocities of $0.13-0.14 \mathrm{cms}^{-1}$ (Lindberg et al., 2002). Major dry deposition of mercury therefore not only occurs near source regions, but also a pronounced amount of deposited mercury is found for the tropics, where the largest quantity of oxidised mercury is found, following the $\mathrm{O}_{3}$ and $\mathrm{OH}$ distribution, as well as the higher temperatures, that favour oxidation reactions of elemental mercury with these two oxidants. Inline with other modelling studies (Seigneur et al., 2004; Selin et al., 2007; Hedgecock et al., 2006) the larger fraction of deposition over Europe and North America is due to dry deposition.

\section{Performance on a multiple-processor linux cluster}

The performance of the coupled modelling system was tested on a Red-Hat Linux cluster with up to 20 (XEON, $3.06 \mathrm{GHz}$ ) processors. Figure 21 shows the performance of the model,

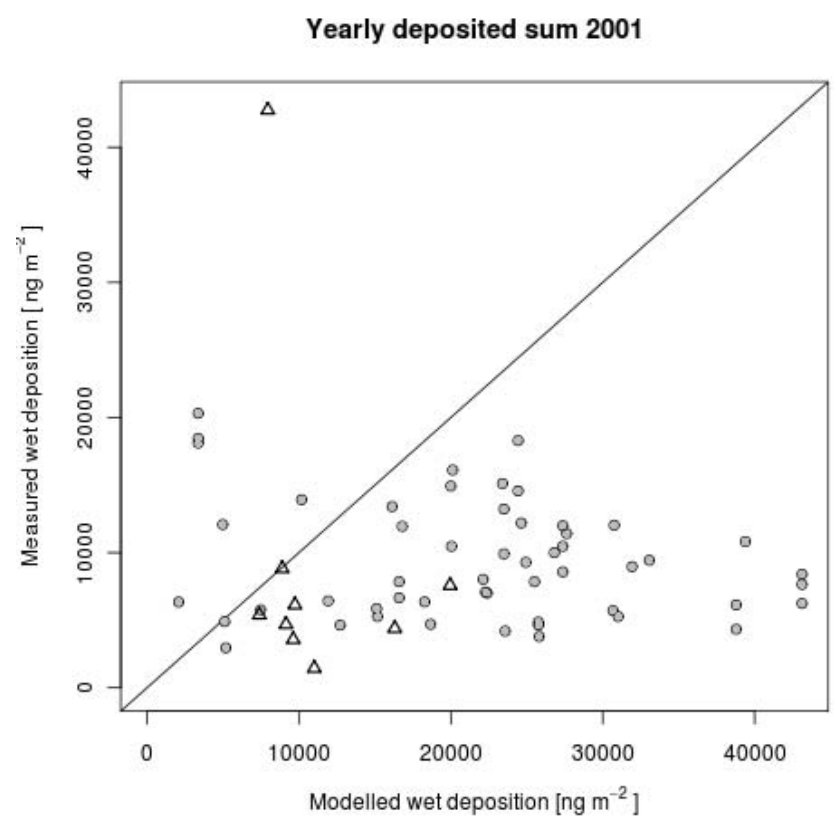

Fig. 19. Simulated versus observed monthly mean $\mathrm{Hg}$ wet deposition $\left[\mathrm{ngm}^{-2}\right]$, circles: MDN data, triangles: EMEP data.

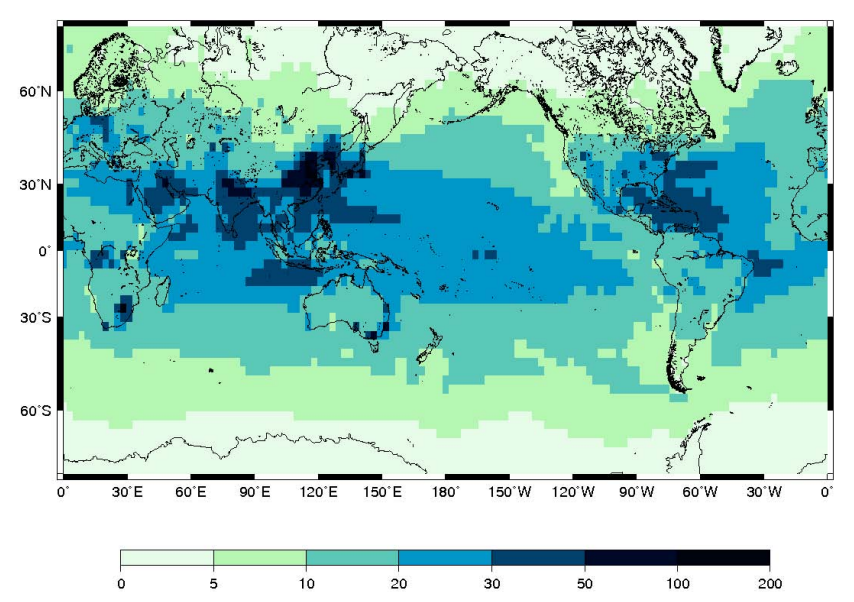

Fig. 20. Annual $\mathrm{Hg}$ dry deposition $\left[\mu \mathrm{gm}^{-2}\right]$.

illustrating ratios of wallclock times, for different model setups and as a function of the number of processors.

First the model performance for a different number of processors was analysed. Figure 21 (top) shows the computing time multiplied by the number of processors divided by the computing time on one processor. This shows the decrease in the benefit of running the model on more cpus with increasing number of cpus. It is demonstrated that up to a number of 20 cpus this decrease is still moderate.

Another performance test was done for the different chemical schemes. First a simulation with only gas phase chemistry was run. The relative increase in simulation time for different runs, including, aqueous, as well as dry chemistry is 

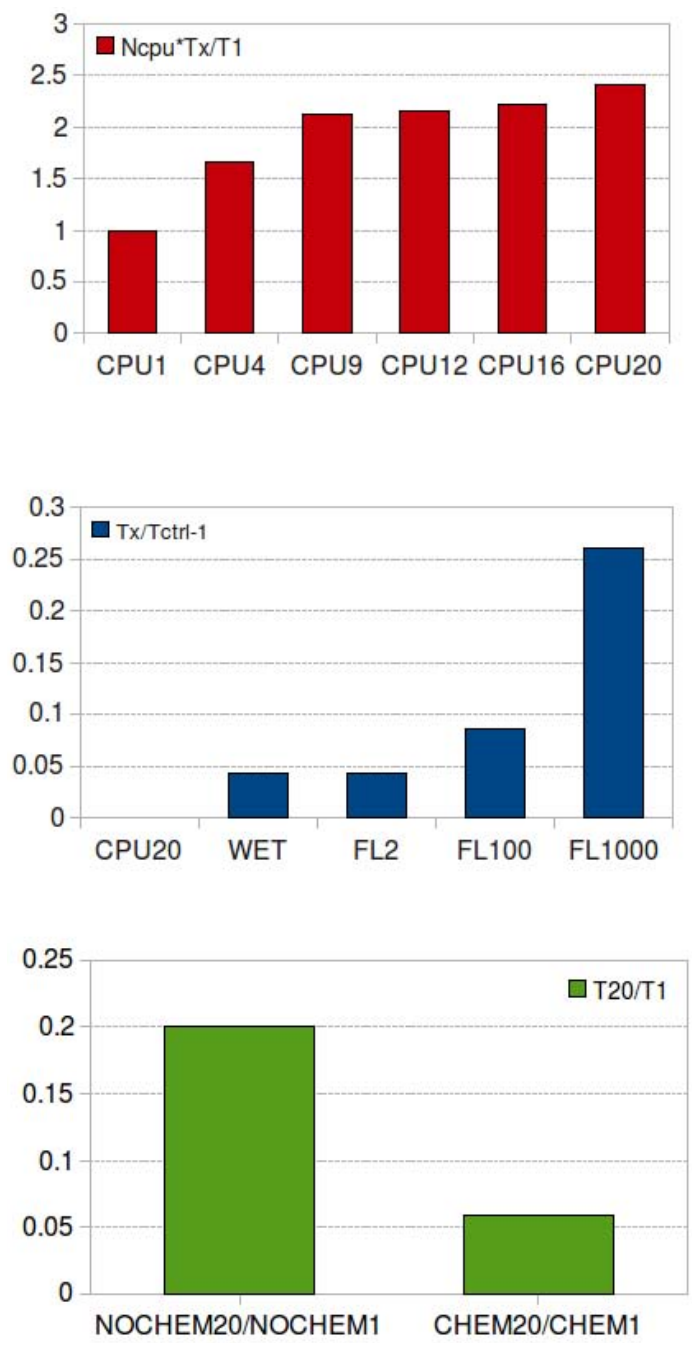

Fig. 21. Model perfomance; top: runtime for different numbers of cpus $\mathrm{x}$ number of cpus with respect to $1 \mathrm{cpu}$, middle: for different chemical schemes (CPU1, CPU4 etc. describe number of CPUs, WET is a full wet and dry chemistry run, FL2-1000 are the number of bins of the droplet size distribution, NOCHEM and CHEM describe runs without and with chemistry, respectively), bottom: advantage of cpu number ECHMERIT and ECHAM5.

then demonstrated in Fig. 21 (middle). Here WET indicated the gas+aqueous phase chemistry scheme with the calculation of the transfer coefficient from the gas phase to cloud droplets assuming a mean droplet radius. The simulations FL2 to FL1000 represent simulations in which the calculation of the averaged mass transfer coefficient was performed dividing the droplet size distribution function into a number of bins from 2 to 1000 . This shows that generally, a large increase in computational time can be expected with an increase in the number of droplet bins used in the calculation. A significant difference in model results, with respect to the number of bins into which the size distribution was divided could only be detected when the number of bins was less than 2 in box model experiments.
The computational time required to run ECHMERIT for a given period with 20 cpus is about $6 \%$ of the time required using $1 \mathrm{cpu}$. In contrast, running ECHMERIT without chemistry included (which is very near to a pure ECHAM5 simulation) on 20 cpus requires approximately $20 \%$ (Fig. 21 bottom) of the time for the run on one cpu only. ECHMERIT (with chemistry) requires almost 20 times as long to perform a simulation for a given period when compared to the original ECHAM5 (no chemistry).

\section{Conclusions and outlook}

The new global mercury-chemistry and transport model ECHMERIT has undergone an initial performance evaluation and a detailed description of all important developed model components was given. These included a precise description of the modules for wet and dry deposition calculation, the implemented emission databases, as well as the chemistry scheme used to simulate tropospheric photochemistry and mercury chemistry. The ECHMERIT model aims to minimize modelling inconsistencies, that are a common problem in CTMs. As ECHMERIT is run in online coupled mode, meteorology, emissions, deposition and chemistry are calculated contemporaneously and on the same model grid. In that way it is aimed at a reduction of modelling uncertainties due to interpolation of meteorological input variables on the CTM model grid and due to the lack of representation of high-frequency meteorology features. ECHMERIT also uses the same convective transport scheme for model physics as for tracer transport. Not doing this can lead to additional inconsistencies, as in common offline coupled models. A study of Grell et al. (2004) for example showed large errors in the vertical mass distribution in a highly resolved regional model when running in offline mode.

A first model evaluation demonstrated a satisfying model performance for ozone and mercury compounds. Some immediately identified problems lie in the inadequate representation of mercury emissions from oceans, vegetation, soils and biomass burning, as these compounds were entirely or partly derived from a mapping of $\mathrm{CO}$ emissions to reported annual mercury emissions. This neglects the fact, that a large amount of so-called natural emissions (from oceans, soils and biosphere) are in fact formerly deposited mercury compounds of anthropogenic origin. Therefore one major task in ongoing model development must be the implementation of improved emission inventories for non-anthropogenic emissions or the development of sophisticated routines for online calculation of natural emissions, for which global soil, ocean and biomass $\mathrm{Hg}$ concentration distributions are necessary. This has a high potential to improve the representation of the assumed hemispheric mercury gradient and the seasonal cycle of mercury concentrations in both hemispheres. As outlined before, also the inclusion of a bromine climatology and an activation of bromine chemistry in ECHMERIT might 
improve the north-south gradient significantly, because from that a stronger mercury depletion over the Southern Hemisphere oceans is expected.

Nevertheless, anthropogenic emissions also have a major uncertainty, because the anthropogenic emission data bases currently available, and used within all global models neglect the temporal variation of mercury emissions. Additionally model improvements could be achieved by introducing volcanic mercury emissions, as well as lightning $\mathrm{NO}_{\mathrm{x}}$ emissions for photochemistry.

Ongoing work includes a precise model validation and statistical analysis for a larger range of tropospheric chemistry variables and based on a larger variety of observational data (surface data, soundings, aircraft measurements, ship cruises etc.). To achieve this task, especially for mercury species an intensification of measurements is important, as one of the main problems regarding model validation lies in the rather small amount of observational data available for mercury compounds. Especially, there is a gap considering almost the entire Southern Hemisphere and oceanic areas and there is also a lack of upper air data and vertical profiles, even though there is recent improvements in this sector what is demonstrated amongst others by Swartzendruber et al. (2006) and Slemr et al. (2009).

Notwithstanding the uncertainties mentioned above, ECHMERIT is suitable for the simulation of mercury chemistry, transport and deposition fluxes on a global scale. ECHMERIT includes state-of-the-art process descriptions of all important processes (emissions, deposition, transport and chemistry) and is characterized by a modular structure and therefore a high level of flexibility that also allows extended sensitivity testing for different chemistry schemes. This is especially useful, because of the uncertainty regarding the tropospheric reactions of mercury and its compounds in the gas and aqueous phases.

Global scale models are useful both for the investigation of intercontinental transport and global scale characteristics of concentration, emission and deposition fields and for the provision of spatio-temporally varying boundary conditions for more detailed regional models.

It has been demonstrated by Pongprueksa et al. (2007) that the model response in $\mathrm{Hg}^{0}$ concentrations to a change in the $\mathrm{Hg}^{0}$ concentration boundary condition was almost linear. Hence the use of fixed boundary conditions of $\mathrm{Hg}^{0}$ in regional models poses the risk of a too strong limitation of elemental mercury concentration variations by the prescribed (fixed) boundary conditions. Global models therefore serve both to identify large scale transport phenomena and synoptic scale source-receptor relationships but also to improve the performance of more detailed, more highly spatially resolved regional models by offering temporally and spatially varying boundary conditions.
Acknowledgements. The authors greatfully acknowledge the Max Planck Institute in Hamburg, Germany for the distribution of their software ECHAM5 and R. A. Zaveri from Atmospheric Sciences and Global Change Division of the Pacific Northwest National Laboratory, Richland, USA for the kind supply of the CBM-Z box model. Additionally the authors like to express their gratitude to I. Kirchner from FU Berlin, Germany for the support concerning the INTERA preprocessor.

Edited by: R. Sander

\section{References}

AMAP/UNEP: Technical Background Report to the Global Atmospheric Mercury Assessment. Arctic Monitoring and Assessment Programme/UNEP Chemicals Branch, 159 pp., online available at: www.chem.unep.ch/mercury/Atmospheric_Emissions/ Technical_background_report.pdf, 2008.

Ariya, P. A., Khalizov, A., and Gidas, A.: Reactions of gaseous mercury with atomic and molecular halogens: kinetics, product studies, and atmospheric implications, J. Phys. Chem. A, 106, 7310-7320, 2002.

Bey, I., Jacob, D. J., Yantosca, R. M., Logan, J. A., Field, B. D., Fiore, A. M., Li, Q., Liu, H. Y., Mickley, L. J., and Schultz, M. G.: Global modeling of tropospheric chemistry with assimilated meteorology- Model description and evaluation, J. Geophys. Res., 106, 23073-23095, 2001.

Brinkop, S. and Sausen, R.: A finite difference approximation for convective transports which maintains positive tracer concentrations, Contributions to Atmospheric Physics, 70, 245-248, 1997.

Bullock, O. R.: Current methods and research strategies for modeling atmospheric mercury, Fuel Processing Technology, 65-66, 459-471, 2000.

CAMx: CAMx, user's guide, version 4.40, Environ International Corporation, California, 2006.

Chang, J. C. and Hanna, S. R.: Air quality model performance evaluation, Meteorol. Atmos. Phys., 87, 167-196, 2004.

Christensen, J. H., Brandt, J., Frohn, L. M., and Skov, H.: Modelling of Mercury in the Arctic with the Danish Eulerian Hemispheric Model, Atmos. Chem. Phys., 4, 2251-2257, 2004, http://www.atmos-chem-phys.net/4/2251/2004/.

Clever, H. L., Johnson, S. A., and Derrick, M. E.: The solubility of Mercury and Some Sparingly Soluble Mercury Salts in Water and Aqueous Electrolyte Solutions, J. Phys. Chem. Refer. Data, 14, 631-680, 1985.

Damian, V., Sandu, A., Damian, M., Potra, F., and Carmichael, G. R.: The kinetic preprocessor KPP: a software environment for solving chemical kinetics, Comput. Chem. Eng., 26, 1567-1579, 2002.

Dastoor, A. P. and Larocque, Y.: Global circulation of atmospheric mercury: a modelling study, Atmos. Environ., 38, 147-161, 2004.

Ebinghaus, R., Kock, H. H., Coggins, A. M., Spain, T. G., Jennings, S. G., and Temme, C.: Long-term measurements of atmospheric mercury at Mace Head, Irish west coast, between 1995 and 2001, Atmos. Environ., 36, 5267-5276, 2002.

Ebinghaus, R., Banic, C., Beauchamp, S., Jaffe, D., Kock, H. H., Pirrone, N., Poissant, L., Sprovieri, F., and Weiss, P. S.: Spatial coverage and temporal trends of land-based atmospheric mercury 
measurements in the northern and southern hemispheres, chapter 9 in: Mercury Fate and Transport in the Global Atmosphere: Measurements, Models and Policy Implications; Interim Report of the UNEP Global Partnership on Atmospheric Mercury Transport and Fate Research, 168-219, 2008.

Eckhardt, S., Stohl, A., Beirle, S., Spichtinger, N., James, P., Forster, C., Junker, C., Wagner, T., Platt, U., and Jennings, S. G.: The North Atlantic Oscillation controls air pollution transport to the Arctic, Atmos. Chem. Phys., 3, 1769-1778, 2003, http://www.atmos-chem-phys.net/3/1769/2003/.

Fortuin, J. and Kelder, H.: An ozone climatology based on ozonesonde and satellite measurements, J. Geophys. Res., 103, 31 709-31 734, 1998.

Friedli, H. R., Arellano, A. F., Cinnirella, S., and Pirrone, N.: Mercury chemical transformation in the gas, aqueous and heterogenous phase: state-of-the-art science and uncertainties, chapter 15 in: Mercury Fate and Transport in the Global Atmosphere: Measurements, Models and Policy Implications; Interim Report of the UNEP Global Partnership on Atmospheric Mercury Transport and Fate Research, 345-376, 2008a.

Friedli, H. R., Arellano, A. F., Cinnirella, S., and Pirrone, N.: Mercury emissions from global biomass burning: spatial and temporal distribution, chapter 8 in: Mercury Fate and Transport in the Global Atmosphere: Measurements, Models and Policy Implications; Interim Report of the UNEP Global Partnership on Atmospheric Mercury Transport and Fate Research, 145-167, 2008b.

Ganzeveld, L. and Lelieveld, J.: Dry deposition parameterization in a chemistry-general circulation model and its influence on the distribution of reactive trace gases, J. Geophys. Res., 100, 20999-21012, 1995.

Ganzeveld, L., Lelieveld, J., and Roelofs, G.-J.: A dry deposition parameterization for sulfur oxides in a chemistry and general circulation model, J. Geophys. Res., 103, 5679-5694, 1998.

Ganzeveld, L. N., van Aardenne, J. A., Butler, T. M., Lawrence, M. G., Metzger, S. M., Stier, P., Zimmermann, P., and Lelieveld, J.: Technical Note: Anthropogenic and natural offline emissions and the online EMissions and dry DEPosition submodel EMDEP of the Modular Earth Submodel system (MESSy), Atmos. Chem. Phys. Discuss., 6, 5457-5483, 2006,

http://www.atmos-chem-phys-discuss.net/6/5457/2006/.

Gårdfeldt, K. and Jonsson, M.: Is bimolecular reduction of $\mathrm{Hg}$ (II) complexes possible in aqueous systems of environmental importance, J. Phys. Chem. A, 107, 4478-4482, 2003.

Granier, C., Lamarque, J. F., Mieville, A., Muller, J. F., Olivier, J., Orlando, J., Peters, J., Petron, G., Tyndall, G., and Wallens, S.: POET, a database of surface emissions of ozone precursors, online available at: http://www.aero.jussieu.fr/projet/ACCENT/ POET.php, 2005.

Grell, G., Knoche, R., Peckham, S., and McKeen, S.: Online versus offline air quality modeling on cloud-resolving scales, Geophys. Res. Lett., 31, L16117, doi:10.1029/2004GL020175, 2004.

Hagemann, S.: An improved land surface parameter dataset for global and regional climate models, Max-Planck-Institut für Meteorologie, 2002.

Hall, B.: The gas phase oxidation of elemental mercury by ozone, Water Air Soil Pollut., 80, 301-315, 1995.

Hall, B. and Bloom, N. S.: Report to the Electric Power Research Institute, Palo Alto, CA, 1993.

Hedgecock, I. M. and Pirrone, N.: Chasing quicksilver: Modeling the atmospheric lifetime of $\mathrm{Hg}^{0}(\mathrm{~g})$ in the marine boundary layer at various latitudes, Environ. Sci. Technol., 38, 69-76, 2004.

Hedgecock, I. M., Trunfio, G. A., Pirrone, N., and Sprovieri, F.: Mercury chemistry in the MBL: Mediterranean case and sensitivity studies using the AMCOTS (Atmospheric Mercury Chemistry over the Sea) model, Atmos. Environ., 39, 7217-7230, doi: 10.1016/j.atmosenv.2005.09.002, 2005.

Hedgecock, I. M., Pirrone, N., Trunfio, G. A., and Sprovieri, F.: Integrated mercury cycling, transport, and air-water exchange (MECAWEx) model, J. Geophys. Res., 111, D20302, doi:10. 1029/2006JD007117, 2006.

Horowitz, L. W., Walters, S., Mauzerall, D. L., Emmons, L. K., Rasch, P. J., Granier, C., Tie, X., Lamarque, J. F., Schultz, M. G., Tyndall, G. S., et al.: A global simulation of tropospheric ozone and related tracers: Description and evaluation of MOZART, version 2, Journal of Geophysical Research, 108(D24), 4784, doi: 10.1029/2002JD002853, 2003.

Hynes, A. J., Donohoue, D. L., Goodsite, M. E., and Hedgecock, I. M.: Our current understanding of major chemical and physical processes affecting mercury dynamics in the atmosphere and at the air-water/terrestrial interfaces, chapter 14 in: Mercury Fate and Transport in the Global Atmosphere: Measurements, Models and Policy Implications Interim Report of the UNEP Global Partnership on Atmospheric Mercury Transport and Fate Research, 322-344, 2008.

Jacobson, M. Z.: Fundamentals of Atmospheric Modeling, Cambridge University Press, 1999.

Jaeglé, L., Strode, S. A., Selin, N. E., and Jacob, D. J.: The GEOSchem model, chapter 18 in: Mercury Fate and Transport in the Global Atmosphere: Measurements, Models and Policy Implications; Interim Report of the UNEP Global Partnership on Atmospheric Mercury Transport and Fate Research, 401-410, 2008.

Kerkweg, A., Buchholz, J., Ganzeveld, L., Pozzer, A., Tost, H., and Jöckel, P.: Technical Note: An implementation of the dry removal processes DRY DEPosition and SEDImentation in the Modular Earth Submodel System (MESSy), Atmos. Chem. Phys., 6, 4617-4632, 2006, http://www.atmos-chem-phys.net/6/4617/2006/.

Lawrence, M. G., Jöckel, P., and von Kuhlmann, R.: What does the global mean $\mathrm{OH}$ concentration tell us?, Atmos. Chem. Phys., 1, 37-49, 2001, http://www.atmos-chem-phys.net/1/37/2001/.

Liang, Q., Jaeglé, L., Jaffe, D. A., Weiss-Penzias, P., Heckman, A., and Snow, J. A.: Long-range transport of Asian pollution to the northeast Pacific: Seasonal variations and transport pathways of carbon monoxide, J. Geophys. Res., 109, D23S07, doi:10.1029/2003JD004402, 2004.

Lin, C.-J. and Pehkonen, S. O.: Aqueous free radical chemistry of mercury in the presence of iron oxides and ambient aerosol, Atmos. Environ., 31, 4125-4137, 1997.

Lin, C.-J. and Pehkonen, S. O.: Aqueous Phase Reactions of Mercury with Free Radicals and Chlorine: Implications for Atmospheric Mercury Chemistry, Chemosphere, 38, 1253-1263, 1999.

Lin, S. J. and Rood, R. B.: Multidimensional Flux-Form SemiLagrangian Transport Schemes, Mon. Weather Rev., 124, 20462070, 1996.

Lindberg, S., Dong, W., and Meyers, T.: Transpiration of gaseous elemental mercury through vegetation in a subtropical wetland in 
Florida, Atmos. Environ., 36, 5207-5219, 2002.

Lindberg, S., Bullock, R., Ebinghaus, R., Engstrom, D., Feng, X., Fitzgerald, W., Pirrone, N., Prestbo, E., and Seigneur, C.: A synthesis of progress and uncertainties in attributing the sources of mercury in deposition, AMBIO, 36, 19-33, 2007.

Lohman, K., Seigneur, C., Gustin, M., and Lindeberg, S.: Sensitivity of the global atmospheric cycle of mercury to emissions, Appl. Geochem., 23, 454-466, doi:10.1016/j.apgeochem.2007. 12.022, 2008.

Lott, F. and Miller, M.: The Representation of Sub-Grid Scale Orography in GCMs, NATO ASI SERIES I Global Environmental Change, 50, 275-290, 1997.

Lubick, N.: Ocean mercury on the increase, Nature, 459, 620-620, doi:10.1038/459620b, 2009.

Mason, R. P.: Mercury emissions from natural sources and their importance in the global mercury cycle, chapter 7 in: Mercury Fate and Transport in the Global Atmosphere: Measurements, Models and Policy Implications; Interim Report of the UNEP Global Partnership on Atmospheric Mercury Transport and Fate Research, 130-144, 2008.

Mueller, J.-F. and Brasseur, G.: IMAGES: a three-dimensional chemical transport model of the global troposphere, J. Geophys. Res., 100, 16445-16490, 1995.

Munthe, J.: The aqueous oxidation of elemental mercury by ozone, Atmos. Environ., 26A, 1461-1468, 1992.

New, M., Hulme, M., and Jones, P.: Representing twentieth century space-time climate variability. Part 1: development of a 1961-90 mean monthly terrestrial climatology, J. Climate, 12, 829-856, 1999.

New, M., Hulme, M., and Jones, P.: Representing twentieth century space-time climate variability. Part 2: development of 1901-96 monthly grids of terrestrial surface climate, J. Climate, 13, 22172238, 2000.

Nordeng, T. E.: Extended Versions of the Convective Parametrization Scheme at ECMWF and Their Impact on the Mean and Transient Activity of the Model in the Tropics, European Centre for Medium-Range Weather Forecasts, 1994.

Pacyna, E. G., Pacyna, J. M., Steenhuisen, F., and Wilson, S.: Global anthropogenic mercury emission inventory for 2000, Atmos. Environ., 40, 4048-4063, 2006.

Pacyna, J. M., Pacyna, E. G., and Aas, W.: Changes of emissions and atmospheric deposition of mercury, lead, and cadmium, Atmos. Environ. International, 43, 117-127, 2009.

Pai, P., Karamchandani, P., and Seigneur, C.: Simulation of the regional atmospheric transport and fate of mercury using a comprehensive Eulerian model, Atmos. Environ., 31, 2717-2732, 1997.

Pal, B. and Ariya, P. A.: Studies of ozone initiated reactions of gaseous mercury: kinetics, product studies, and atmospheric implications, Phys. Chem. Chem. Phys., 6, 572-579, 2004.

Pehkonen, S. O. and Lin, C.-J.: Aqueous photochemistry of mercury with organic acids, J. Air Waste Manage. Assoc. (1995), 48, 144-150, 1998.

Peters, J. A. H. W. and Olivier, J. G. J.: EDGAR3/POET Enussuibs; 1997 emissions and scenarios for 1995-2020; Technical background infromation on global and regional sectoral emissions, RIVM, Bilthoven, report no. 773301003, 2003.

Pirrone, N. and Mason, R.: Mercury Fate and Transport in the Global Atmosphere: Measurements, Models and Policy Implications Interim Report of the UNEP Global Partnership on At- mospheric Mercury Transport and Fate Research, 2008.

Pirrone, N. and Mason, R. (Eds.): Mercury Fate and Transport in the Global Atmosphere: Emissions, Measurements and Models, Springer, USA, 2009.

Pirrone, N., Keeler, G. J., and Nriagu, J. O.: Regional differences in worldwide emissions of mercury to the atmosphere, Atmos. Environ., 17, 2981-2987, 1996.

Pleijel, K. and Munthe, J.: Modelling the Atmospheric Mercury Cycle - Chemistry in Fog Droplets, Atmos. Environ., 29, 14411457, 1995.

Pongprueksa, P., Lin, C. J., Lindberg, S. E., Jang, C., Braverman, T., Russell Bullock, O., Ho, T. C., and Chu, H. W.: Scientific uncertainties in atmospheric mercury models III: Boundary and initial conditions, model grid resolution, and $\mathrm{Hg}$ (II) reduction mechanism, Atmos. Environ., 42, 1828-1845, 2007.

Roeckner, E., Baeuml, G., Bonventura, L., Brokopf, R., Esch, M., Giorgetta, M., Hagemann, S., Kirchner, I., Kornblueh, L., Manzini, E., Rhodin, A., Schlese, U., Schulzweida, U., and Tompkins, A.: The atmospheric general circulation model ECHAM5. PART I: Model description, Report 349, Max Planck Institute for Meteorology, Hamburg, Germany, 2003.

Roeckner, E., Brokopf, R., Esch, M., Giorgetta, M., Hagemann, S., Kornblueh, L., Manzini, E., Schlese, U., and Schulzweida, U.: Sensitivity of Simulated Climate to Horizontal and Vertical Resolution in the ECHAM5 Atmosphere Model, J. Climate, 19, 3771-3791, 2006.

Sander, R.: Modeling Atmosheric Chemistry: Interactions between Gas-Phase Species and Liquid Cloud/Aerosol Particles, Survey Geophys., 20, 1-31, 1999.

Sander, R., Kerkweg, A., Jöckel, P., and Lelieveld, J.: Technical note: The new comprehensive atmospheric chemistry module MECCA, Atmos. Chem. Phys., 5, 445-450, 2005, http://www.atmos-chem-phys.net/5/445/2005/.

Sandu, A. and Sander, R.: Technical note: Simulating chemical systems in Fortran90 and Matlab with the Kinetic PreProcessor KPP-2.1, Atmospheric Chemistry and Physics, 6, 187-195, 2006.

Schroeder, W. H., Anlauf, K.-G., Barrie, L. A., Lu, J. Y., Steffen, A., Schneeberger, D. R., and Berg, T.: Arctic springtime depletion of mercury, Nature, 394, 331-332, 1998.

Schulzweida, U., Kornblueh, L., and Quast, R.: CDO User's Guide, Climate Data Operators, Version 1.0.7, Tech. rep., online available at: www.mpimet.mpg.de/fileadmin/software/cdo/, 2007.

Schwartz, S. E.: Mass-transport considerations pertinent to aqueous phase reactions of gases in liquid-water clouds, pp. 415-471, in: W. Jaeschle, Editor, Chemistry of Multiphase Atmospheric Systems NATO ASI Series G6, Springer Berlin Heidelberg, Germany, 1986.

Seigneur, C., Lohman, K., Vijayaraghavan, K., and Shia, R.-L.: Multiscale modeling of the atmospheric fate and transport of mercury, J. Geophys. Res., 106(D21), 27795-27809, 2001.

Seigneur, C., Karamchandani, P., Vijayaraghavan, K., Lohman, K., Shia, R. L., and Levin, L.: On the effect of spatial resolution on atmospheric mercury modeling, Sci. Total Environ., 304, 73-81, 2003.

Seigneur, C., Vijayaraghavan, K., Lohmann, K., Karamchandani, P., and Scott, C.: Global source attribution for mercury deposition in the United States, Environ. Sci. Technol., 38, 555-569, 2004. 
Seigneur, C., Vijayaraghavan, K., and Lohman, K.: Atmospheric mercury chemistry: sensitivity of global model simulations to chemical reactions, J. Geophys. Res.-Atmospheres, 111, D22306, doi:10.1029/2005JD006780, 2006.

Seinfeld, C. P. and Pandis, S. N.: Atmospheric Chemistry and Physics, From Air Pollution to Climate Change, 1998.

Selin, N. E., Jacob, D. J., Park, R. J., Yantosca, R. M., Strode, S., Jaeglé, L., and Jaffe, D.: Chemical cycling and deposition of atmospheric mercury: Global constraints from observations, J. Geophys. Res., 112, D02308, doi:10.1029/2006JD007450, 2007.

Sellers, P. J., Mintz, Y., Sud, Y. C., and Dalcher, A.: A simple biosphere model $(\mathrm{SiB})$ for use within general circulation models, J. Atmos. Sci., 43, 505-531, 1986.

Slemr, F. and Scheel, H. E.: Trends in atmospheric mercury concentrations at the summit of the Wank mountain, Southern Germany, Atmos. Environ., 32, 845-853, 1998.

Slemr, F., Brunke, E. G., Ebinghaus, R., Temme, C., Munthe, J., Wängberg, I., Schroeder, W., Steffen, A., and Berg, T.: Worldwide trend of atmospheric mercury since 1977, Geophys. Res. Lett., 30(10), 1516, doi:10.1029/2003GL016954, 2003.

Slemr, F., Ebinghaus, R., Brenninkmeijer, C. A. M., Hermann, M., Kock, H. H., Martinsson, B. G., Schuck, T., Sprung, D., van Velthoven, P., Zahn, A., and Ziereis, H.: Gaseous mercury distribution in the upper troposphere and lower stratosphere observed onboard the CARIBIC passenger aircraft, Atmos. Chem. Phys., 9, 1957-1969, 2009, http://www.atmos-chem-phys.net/9/1957/2009/.

Slinn, S. A. and Slinn, W. G. N.: Prediction for particle deposition of natural waters, Atmos. Environ., 14, 1013-1016, 1980.

Sommar, J., Hallquist, M., Ljungström, E., and Lindqvist, O.: On the gas phase reactions between volatile biogenic mercury species and the nitrate radical, J. Atmos. Chem., 27, 233-247, 1997.

Sommar, J., Gårdfeldt, K., Strömberg, D., and Feng, X.: A kinetic study of the gas-phase reaction between the hydroxyl radical and atomic mercury, Atmos. Environ., 35, 3049-3054, 2001.

Sprovieri, F., Pirrone, N., Hedgecock, I. M., Landis, M. S., and Stevens, R. K.: Intensive atmospheric mercury measurements at Terra Nova Bay in Antarctica during November and December 2000, J. Geophys. Res., 107(D23), 4722, doi:10.1029/ 2002JD002057, 2002.

Stohl, A., Eckhardt, S., Forster, C., James, P., and Spichtinger, N.: On the pathways and timescales of intercontinental air pollution transport, J. Geophys. Res., 107(D23), 4684, doi:10.1029/ 2001JD001396, 2002.

Streets, D., Zhang, Q., and Wu, Y.: Projections of Global Mercury Emissions in 2050, Environ. Sci. Technol., 43, 2983-2988, 2009.

Swartzendruber, P. C., Jaffe, D. A., M.Prestbo, E., Weiss-Penzias, P., Selin, N. E., Park, R., Jacob, D. J., Strode, S., and Jaeglé, L.: Observations of reactive gaseous mercury in the free troposphere at the Mount Bachelor Observatory, J. Geophys. Res., 111, D24301, doi:10.1029/2006JD007415, 2006.

Taylor, K. E., Williamson, D., and Zwiers, F.: AMIPII Sea Surface Temperature and Sea Ice Concentration Boundary Conditions, 1997.
Thompson, A., Witte, J., McPeters, R., Oltmans, S., Schmidlin, F., Logan, J., M.Fujiwara, Kirchhoff, V., Posny, F., Coetzee, G., Hoegger, B., Kawakami, S., Ogawa, T., Johnson, B., Vömel, H., and Labow, G.: Southern Hemisphere Additional Ozonesondes (SHADOZ) 1998-2000 tropical ozone climatology 1. Comparison with Total Ozone Mapping Spectrometer (TOMS) and ground-based measurements, J. Geophys. Res., 108, D28238, doi:10.1029/2001JD000967, 2003.

Tiedtke, M.: A Comprehensive Mass Flux Scheme for Cumulus Parameterization in Large-Scale Models, Mon. Weather Rev., 117, 1779-1800, 1989.

Tokos, J. J. S., Hall, B., Calhoun, J. A., and Prestbo, E. M.: Homogeneous gas-phase reaction of $\mathrm{Hg}^{0}$ with $\mathrm{H}_{2} \mathrm{O}_{2}, \mathrm{O}_{3}, \mathrm{CH}_{3} \mathrm{I}$, and $\left(\mathrm{CH}_{3}\right)_{2} \mathrm{~S}$ : Implications for atmospheric $\mathrm{Hg}$ cycling, Atmos. Environ.(1994), 32, 823-827, 1998.

Tost, H., Jöckel, P., and Lelieveld, J.: Influence of different convection parameterisations in a GCM, Atmos. Chem. Phys., 6, 54755493, 2006, http://www.atmos-chem-phys.net/6/5475/2006/.

Travnikov, O.: Contribution of the intercontinental atmospheric transport to mercury pollution in the Northern Hemisphere, Atmos. Environ., 39, 7541-7548, 2005.

Van Loon, L. L., Mader, E. A., and Scott, S. L.: Sulfite Stabilization and Reduction of the Aqueous Mercuric Ion: Kinetic Determination of Sequential Formation Constants, J. Phys. Chem. A., 105, 3190-3195, 2001.

Vermette, S., Lindberg, S., and Bloom, N.: Field tests for a regional mercury deposition networksampling design and preliminary test results, Atmos. Environ., 29, 1247-1251, 1995.

Vijayaraghavan, K., Karamchandani, P., Seigneur, C., Balmori, R., and Chen, S. Y.: Plume-in-grid modeling of atmospheric mercury, J. Geophys. Res.-Atmos., 113, D24305, doi:10.1029/ 2008JD010580, 2008.

Wang, Z. and Pehkonen, S. O.: Oxidation of elemental mercury by aqueous bromine: atmospheric implications, Atmos. Environ., 38, 3675-3688, 2004.

Wesely, M. L.: Parameterization of the surface resistances to gaseous dry deposition in regional-scale numerical models, Atmos. Environ., 23, 1293-1304, 1989.

Wesely, M. L. and Hicks, B. B.: Some factors that affect the deposition rates of sulfur dioxide and similar gases on vegetation, Journal of Air Pollution Control Assessment, 27, 1110-1116, 1977.

Wesely, M. L. and Hicks, B. B.: A review of the current status of knowledge on dry deposition, Atmos. Environ., 34, 2261-2282, 2000.

Wild, O., Zhu, X., and Prather, M. J.: Fast-J: Accurate Simulation of In-and Below-Cloud Photolysis in Tropospheric Chemical Models, J. Atmos. Chem., 37, 245-282, 2000.

Yang, X., Cox, R., Warwick, N., Pyle, J., Carver, G., O'Connor, F., and Savage, N.: Tropospheric bromine chemistry and its impacts on ozone: A model study, J. Geophys. Res.-Atmos., 110, D23311, doi:10.1029/2005JD006244, 2005.

Zaveri, R. A. and Peters, L. K.: A new lumped structure photochemical mechanism for large-scale applications, J. Geophys. Res., 104, 30387-30415, 1999. 